\title{
Peranan Pemimpin dalam Pelaksanaan Etika Kerja Islam: Kajian Kes di Johor Corporation (JCorp)
}

\author{
Siti Arni Basir \\ Universiti Malaya, sitiarni@um.edu.my \\ Nurul Syafiyah Mohd Noor \\ Universiti Malaya, nurulsyafiyah.mohdnoor@gmail.com \\ Mohamad Zaidi Abd Rahman \\ Universiti Malaya,mzaidi@um.edu.my \\ Monika@ Munirah Abd Razzak \\ Universiti Malaya,munirahar@um.edu.my
}

\begin{abstract}
Abstrak
Pelaksanaan etika kerja Islam di mana-mana organisasi memerlukan kerjasama pelbagai pihak, termasuklah kerjasama daripada pihak pemimpin organisasi. Pemimpin memainkan peranan kepimpinan iaitu kebolehan untuk membawa bersama-sama semua ahli organisasi untuk bekerjasama secara sukarela ke arah pencapaian matlamat organisasi yang telah ditetapkan. Walaupun banyak kajian mengenai etika kerja Islam telah dijalankan oleh sarjana terdahulu, tetapi kajian mengenai peranan pemimpin dalam pelaksanaan etika kerja Islam masih amat kurang dijalankan. Oleh itu, objektif kajian ini ialah untuk mengenalpasti dan mengkaji tentang peranan pemimpin dalam pelaksanaan etika kerja Islam di Malaysia. Organisasi yang dipilih untuk kajian ini ialah Johor Corporation atau JCorp. Kajian ini bersifat kualitatif dengan menggunakan dokumen sebagai sumber utama data. Laporan-laporan Tahunan JCorp, buku terbaru dan keratan-keratan akhbar yang ditulis oleh mantan Ketua Pegawai Eksekutif JCorp merupakan dokumendokumen yang dirujuk dalam kajian ini. Metod analisis tematik telah digunakan untuk menganalisis data yang telah dikumpulkan. Melalui kaedah ini, tema-tema mengenai peranan pemimpin dalam pelaksanaan etika kerja Islam di JCorp telah ditemui dan dibincangkan secara menyeluruh. Hasil kajian menunjukkan pemimpin organisasi korporat JCorp telah memainkan 6 peranan penting dalam perlaksanaan etika kerja Islam. 6 peranan tersebut ialah berkenaan dengan latihan, komunikasi, pembuatan keputusan, pemantauan, sistem ganjaran dan persekitaran. Kesemua 6 peranan tersebut telah berfungsi sebagai faktor pemangkin yang menyuburkan pelaksanaan etika kerja Islam di JCorp. Hasil kajian ini boleh digunakan sebagai garis panduan kepada pemimpin organisasi korporat lain di Malaysia dalam usaha mereka untuk melaksanakan etika kerja Islam secara efektif di organisasi masing-masing.
\end{abstract}

Kata kunci: etika kerja Islam, pelaksanaan, peranan pemimpin, JCorp, kajian kes 


\title{
The Role of Leader in Islamic Work Ethics Implementation:
}

\section{A Case Study in Johor Corporation (JCorp)}

\begin{abstract}
Implementation of Islamic work ethics in any organization requires cooperation of various parties, including cooperation from leaders of organization. Leaders play a leadership role because they have the ability to bring together all members of organizations to voluntarily work together towards achievement of organizational goals. Although many studies in regard to Islamic work ethics have been carried out by previous scholars, but studies on the role of leader in the implementation of Islamic work ethics is still very much lacking. Therefore, the objective of this paper is to study the role of leader in the implementation of Islamic work ethics in Malaysia. The case study organization selected for this study is Johor Corporation or JCorp. This is a qualitative study using data from documents as a primary source. The JCorp annual reports, latest book and newspaper articles written by a former Chief Executive Officer (CEO) of JCorp are the documents referred to in this study. The method of thematic analysis was used to analyze the data collected. Through this method, the themes of the role of leader in the implementation of Islamic work ethics in JCorp was discovered and discussed thoroughly. The research findings from this present study found that corporate leaders of JCorp had played six vital roles in the implementation of Islamic work ethics. The six roles are in respect of training, communication, decision making, monitoring, reward systems and environments. All six roles are functioning as a catalyst factor to cultivate Islamic work ethics implementation in JCorp. The findings of this study can be used as a guideline to leaders of other Malaysian corporate organizations in their efforts to implement Islamic work ethics effectively.
\end{abstract}

Keywords: Islamic work ethics, implementation, leadership role, JCorp, case study

\section{Pendahuluan}

Persaingan dalam sektor awam mahupun swasta dalam dunia global hari ini amat mencabar. Justeru adalah menjadi keperluan kepada sesebuah organisasi untuk memiliki barisan pengurusan dan pekerja yang komited dalam memenuhi aspirasi misi dan visi organisasi. Dalam usaha organisasi mengenalpasti golongan pekerja yang akan memberikan komitmen yang tinggi terhadap organisasi, kepekaan terhadap pegangan etika kerja seseorang individu adalah sangat penting. 
Antara isu-isu yang sering timbul berkaitan dengan etika kerja di sesebuah organisasi adalah rasuah, ketirisan dan penyalahgunaan kuasa. Perkara ini dikuatkan lagi, dengan statistik yang ditunjukkan oleh Suruhanjaya Pencegah Rasuah Malaysia (SPRM) pada Januari 2015 bahawa sebanyak 51 orang terlibat dalam tangkapan rasuah. Daripada jumlah tersebut, 13 orang merupakan mereka yang dikategorikan dari kumpulan pengurusan dan profesional ${ }^{1}$.

Perkara ini amat membimbangkan, kerana ia berlaku dalam kalangan mereka yang berjawatan tinggi dan menerajui kepimpinan organisasi. Lebih membimbangkan lagi jika pemimpin tersebut tidak sedar bahawa mereka telah terjebak dengan gejala-gejala seperti rasuah, pecah amanah, menyalah gunakan kuasa, boros dan sebagainya. Oleh itu, etika menurut Islam dianggap sangat penting dan relevan bagi pengurus dan pemimpin organisasi masa kini dan diharapkan etika tersebut dapat menjamin mereka agar tidak menyimpang dari landasan yang sebenar ${ }^{2}$. Sehubungan dengan ini, pihak pengurusan atasan ataupun pemimpin organisasi disarankan untuk menunjukkan contoh etika yang baik agar ia menjadi contoh kepada orang lain ${ }^{3}$.

Kajian empirikal mengenai pelaksanaan etika kerja Islam telah banyak dijalankan oleh para sarjana, tetapi kajian-kajian tersebut lebih tertumpu kepada jenis etika Islam dan perlaksanaannya. Kajian-kajian tersebut telah dijalankan oleh (Yousef, 2001; Rokhman, 2010; Ali dan Al-Kazemi, 2007; AlA'ali, 2008; Nor Azzah, 2007; Khalil dan Abu-Saad, 2009; Abdallah, 2010; Rose dan Kumar, 2010; Rose dan Kumar, 2012; dan, Nor Azzah dan Siti Arni, 2013). Manakala kajian spesifik

1 Suruhanjaya Pencegah Rasuah Malaysia (SPRM) 2015, "Statistik Tangkapan 2015", dicapai 25 Februari 2015, http://www.sprm.gov.my/statistik-tangkapantahunan-2015.html.

2 Sheikh Abdul Munir bin Sheikh Abdul Rahim, "Etika Kepimpinan Menurut Islam: Suatu Kajian di Kalangan Pemimpin Melayu Peringkat Negeri di Pahang Darul Makmur", (Disertasi, Universiti Malaya, Kuala Lumpur, 2008), 28.

3 Nor Azzah Kamri dan Siti Arni Basir, "Etika di Institusi Islam: Penelitian Ke Atas Faktor Pendorong Pelaksanaannya", dalam Islamic Perspective On Management: Contemporary Issues, ed. Nor Azzah Kamri, Azian Madun. and Suhaili Sarif (Kuala Lumpur: Akademi Pengurusan YaPIEM, 2013), 3-23 
mengenai etika kerja Islam dan kaitannya dengan aspek kepimpinan organisasi belum lagi dijalankan.

Nor Azzah dan Siti Arni (2013) ${ }^{4}$ telah menyatakan secara sepintas lalu bahawa pihak organisasi telah mengambil langkah sewajarnya dalam perlaksanaan etika kerja Islam. Tetapi penulispenulis tersebut tidak menyentuh secara spesifik tentang peranan pemimpin organisasi dalam pelaksanaan etika kerja Islam.

Daripada kajian yang dijalankan terhadap ulamak, golongan dewasa dan golongan belia di Pakistan ${ }^{5}$, mendapati bahawa peranan Ketua Pegawai Eksekutif atau pemimpin organisasi dalam menyampaikan seruan Allah sebenarnya merupakan peranan yang penting. Ini kerana peranan tersebut akan membawa kesan memberangsangkan kepada penyuburan budaya beretika di tempat kerja. Walaupun Khasif et al. (2015) ${ }^{6}$ menekankan kepentingan peranan pemimpin organisasi dalam menyuburkan penyuburan budaya beretika berteraskan Islam di tempat kerja, namun setakat ini tiada kajian empirikal yang secara khusus dijalankan untuk mengkaji topik tersebut.

Literatur menunjukkan terdapat kelompangan yang besar mengenai topik yang berkaitan dengan peranan pemimpin dalam pelaksanaan inisiatif etika kerja Islam di organisasi. Oleh itu, kajian mengenai kaitan antara pemimpin dan pelaksanaan etika kerja Islam amat perlu dijalankan. Objektif kajian ini adalah untuk mengenalpasti dan mengkaji tentang peranan pemimpin dalam pelaksanaan etika kerja Islam di Malaysia. Organisasi yang dipilih untuk kajian ini ialah sebuah organisasi korporat yang tersohor di Malaysia iaitu Johor Corporation (JCorp).

\section{Literatur Kepentingan Pemimpin dalam Islam}

Subjek kepimpinan memang menjadi pusat perhatian kajian dalam wacana ilmu-ilmu Islam. Malahan keseriusan subjek ini diangkat dalam perbahasan akidah hingga ke tahap kesempurnaan iman bergantung kepada bulatnya keyakinan kepada imam yang

\footnotetext{
${ }^{4}$ Azzah dan Siti Arni, Etika di Institusi Islam, 3-23, t.h.

5 Khasif Muhammad, Run Ernest Cyril De, Abdul Rehman Mohsin and Ting Hiram, "Bringing Islamic Tradition Back to Management Development: A New Islamic Dawah Based Framework to Foster Workplace Ethics", Journal of Islamic Marketing 6, no 3, (2015), 429-446.

6 Khasif Muhammad et al., Bringing Islamic Tradition Back, 429-446, t.h.
} 
ditentukan (dari ahl al-Bayt sahaja) sebagaimana dalam tradisi akidah Syiah. Bagi kalangan aliran arus perdana Islam (Ahl alSunnah wa al-Jama'ah) pula sekalipun tidak menentukan kepimpinan hanya dipilih dari jalur keturunan tertentu, namun perhatian besar turut diberikan kepada subjek ini lantaran ia adalah sebahagian dari peraturan Syariat.

Sebelum dibincang dengan lebih lanjut, adalah lebih baik untuk melihat penggunaan istilah kepimpinan di dalam al-Quran. Secara amnya didapati empat istilah yang diguna pakai iaitu seperti berikut:

\section{a. Khalifah}

Khalifah menurut bahasa bermaksud menggantikan atau menempati tempatnya atau orang yang datang setelah orang lain, lalu menggantikan tempatnya ${ }^{7}$. Ini berdasarkan firman Allah dalam surah al-Baqarah (2):30 dan al-A'rāf (7): 142

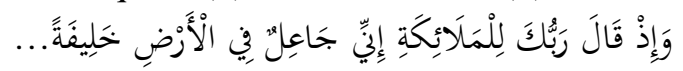

Terjemahan: "Dan (ingatlah) ketika Tuhanmu berfirman kepada Malaikat: "Sesungguhnya Aku hendak menjadikan seorang khalifah di bumi".

$$
\text { وَقَالَ مُوسَى لِالَخِيِهِ هَارُونَ انْلُفْنِي فِيَ قَوْبِي }
$$

Terjemahan: "Berkata Musa kepada saudaranya, Harun, "Gantikanlah aku dalam (memimpin) kaumku."

Bagi ayat pertama, kebanyakan mufasir telah mengumumkan pengganti kepimpinan ini bukan terhad kepada Nabi Adam semata-mata (al-Qurțubī: t.t. ${ }^{8}$; al-Rāzì: $2000^{9}$; al-Zamakhsharīi: $2009^{10}$ dan al-Baghawi: $2012^{11}$ ). Manakala ayat kedua, mufasir telah menyatakan berlakunya gantian kepimpinan dari Nabi Musa

\footnotetext{
Muhammad Ibn Mukarram Ibn Manẓūr, Lisān, al- 'Arab (Beirut: Dār al-Iḥyā' Turath al-'Arabiy, 1988), jil $12 \& 15$.

8 Abū 'Abd Allāh Muhammad bin Aḥmad al-Anșārī al-Qurțubī, al-Jāmi' li Ahkām al-Qur'an, Tahq. 'Imād Zakī al-Barudī \& Khawrī Sa'īd (Kaherah: alMaktabah al-Tawfiqiyyah, t.t.), j. 1, t.h.

9 Fakhr al-Dīn 'Umar bin al-Ḥusayn al-Taymī al-Bakrī al-Razī, Tafsīr al-Kabīr (Beirut: Dār al-Kutub al-'Ilmiyyah, 2000).

${ }^{10}$ Abū Qāsīm al-Zamakhsharī, Al-Kashshāf, Cet. 3 (Beirut: Dār al-Ma‘rifah, 2009), j.1, t.h.

${ }^{11}$ Abū Muhammad al-Husayn Ibn Mas'ūd Ibn Muhammad al-Farra' al-Baghāwī, Ma 'àim al-Tanzīl (Lubnan: Dār al-Ma'rifah, 2012), j. 1, t.h.
} 
kepada Nabi Harun untuk satu tempoh tertentu (Ibn Kathīr: $2002^{12}$ dan al-Zuhaylī: $1997^{13}$ ). Dalam pengertian syarak pula, khilafah digunakan untuk menyebut orang yang menggantikan Nabi SAW dalam kepemimpinan negara Islam. Khilafah adalah kepemimpinan umum bagi kaum muslimin seluruhnya di dunia, untuk menegakkan hukum-hukum syariah Islam dan mengembang dakwah Islamiyah ke seluruh dunia. Kesimpulannya khalifah adalah orang yang mewakili umat dalam urusan kekuasaan dan penerapan hukum-hukum syarak.

\section{b. Ulu al-'Amr}

Ulu al-'Amr terdiri dari dua kata iaitu Ulu yang bermaksud pemilik dan al-' Amr bermaksud urusan, perkara atau perintah. Jika digandingkan ia bermaksud pemilik urusan atau pemilik kekuasaan. Allah berfirman:

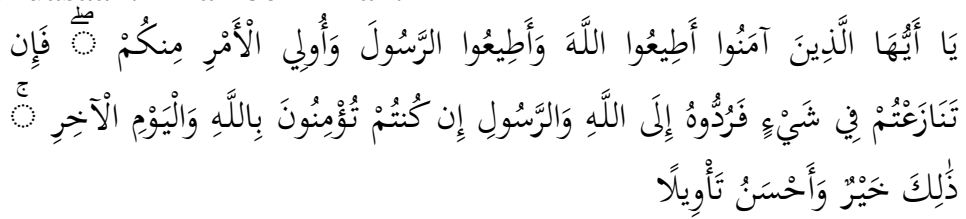

al-Nisā'4:59

Terjemahan: "Wahai orang-orang yang beriman, taatlah kamu kepada Allah dan taatlah kamu kepada Rasulullah dan kepada "Ulil-Amri" (orang-orang yang berkuasa) dari kalangan kamu. Kemudian jika kamu berbantah-bantah (berselisihan) dalam sesuatu perkara, maka hendaklah kamu mengembalikannya kepada (Kitab) Allah (Al-Quran) dan (Sunnah) RasulNya- jika kamu benar beriman kepada Allah dan hari akhirat. Yang demikian adalah lebih baik (bagi kamu), dan lebih elok pula kesudahannya".

Ayat di atas menerangkan Ulu al-'Amr adalah mereka yang memilikki ilmu dan pengetahuan fiqh. Sebahagian mufasir yang lain berpendapat bahawa sahabat-sahabat Rasulullah SAW itulah

${ }^{12}$ Abū al-Fiḍā' Ismā'īl al-Qurashiy al-Dimashq̄i Ibn Kathir, Tafsìr alQur'an al-'Ażìm (Kaherah: Dār al-Hadīth, 2002), j.1, t.h.

13 Wahbah al-Zuhayli, al-Fiqh al-Islāmī wa Adillatuh. Cet. 4 (Dimashq: Dār alFikr, 1997), j.1, t.h. 
yang dimaksud dengan ulu al-'Amr ${ }^{14}$. Manakala al-Mawardī memberi empat pengertian iaitu pertama umāra' (para pemimpin), kedua ulama dan fuqaha, ketiga sahabat-sahabat Rasulullah s.a.w., keempat dua sahabat saja, iaitu Abu Bakar dan Umar ${ }^{15}$. Sementara al-Maraghi menyatakan ia adalah umāra', ahli hikmah, ulama, pemimpin pasukan dan seluruh pemimpin lainnya ${ }^{16}$.

\section{b. Imam}

Perkataan imam mempunyai maksud seperti seorang yang diikuti seperti imam solat, ketua sesuatu kaum dan pemimpin kepada masyarakat ${ }^{17}$. Istilah ini terdapat pada firman Allah SWT:

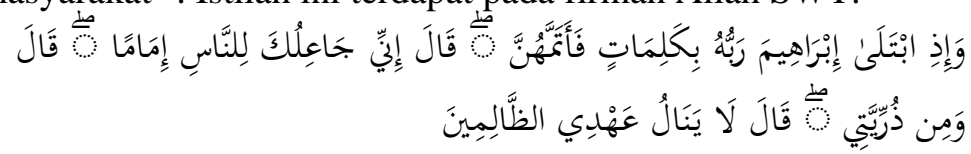

Al-Baqarah 2:124

Terjemahan: "Dan (ingatlah), ketika Nabi Ibrahim diuji oleh Tuhannya dengan beberapa Kalimah (suruhan dan larangan), maka Nabi Ibrahim pun menyempurnakannya. (Setelah itu) Allah berfirman: "Sesungguhnya Aku melantikmu menjadi Imam (Pemimpin ikutan) bagi umat manusia". Nabi Ibrahim pun memohon dengan berkata: "(Ya Tuhanku!) Jadikanlah juga (apalah jua kiranya) dari keturunanku (pemimpinpemimpin ikutan)". Allah berfirman: "(Permohonanmu diterima, tetapi) janjiKu ini tidak akan didapati oleh orangorang yang zalim."

Mufassir seperti Ibn Kathīi ${ }^{18}$ dan al-Qurțubî ${ }^{19}$ menyatakan Nabi Ibrahim adalah imam kepada kaumnya, menjadi contoh ikutan yang baik kepada orang lain untuk diteladani. Begitu juga sebahagian dari zuriat keturunannya turut menjadi imam (pemimpin). Oleh itu para ulama rata-rata mendefinisikan imam

\footnotetext{
${ }^{14}$ Abū Ja'far Muhammad bin Jarīr al-Ṭabarī, Jāmi' al-Bayān 'an Ta'wīl alQur'ān. Cet. 3 (Mesir: Sharikah Maktabah wa Țab'ah Mușțafā al-Bābī alḤalabī wa Awlāduh, 1968), j.2, t.h.

15 Abu Hasan Al-Mawardi, Al-Nukat wa al-'Uyūn (Beirut: Dār al-Kutub al'Ilmiyyah, t.t.), t.h.

${ }^{16}$ Aḥmad Mușțafā al-Maraghī, Tafsīr al-Maraghī (Beirut: Dār al-Fikr, 1974).

${ }^{17}$ Muhammad Ibn Mukarram Ibn Manzūur, Lisān al- 'Arab (Beirut: Dar al-Ihya' Turath al-'Arabi, 1988), j. 12 \& 15, t.h.

${ }^{18}$ Ibn Kathīr, Tafsìr al-Qur'an al-'Azīim.

${ }^{19}$ Al-Qurțubī, Al-Jāmi` li Aḥkām al-Qur'ān.
} 
itu sebagai setiap orang yang dapat diikuti dan ditampilkan ke depan dalam pelbagai urusan. Sebagai contoh, Rasulullah adalah imam, dan al-Qur'an itu adalah juga imam kepada umat Islam. Pada kebiasaanya, manusia diikuti kerana perkataan dan perbuatannya. Manakala kitab dari sudut idea dan gagasangagasan yang terkandung di dalamnya. Ikutan tersebut boleh berlaku dalam perkara kebaikan mahupun keburukan.

\section{c. Malik}

Bagi istilah malik atau raja, ia merujuk kepada firman Allah:

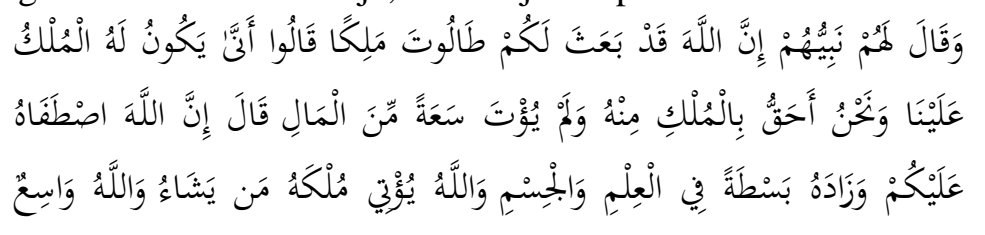

Al-Baqarah 2:247

Terjemahan: "Dan Nabi mereka pula berkata kepada mereka: "Bahawasanya Allah telah melantik Talut menjadi raja bagi kamu. Mereka menjawab: "Bagaimana dia mendapat kuasa memerintah kami sedang kami lebih berhak dengan kuasa pemerintahan itu daripadanya, dan ia pula tidak diberi keluasan harta kekayaan?" Nabi mereka berkata": Sesungguhnya Allah telah memilihnya (Talut) menjadi raja kamu, dan telah mengurniakannya kelebihan dalam lapangan ilmu pengetahuan dan kegagahan tubuh badan". Dan (ingatlah), Allah jualah yang memberikan kuasa pemerintahan kepada sesiapa yang dikehendakiNya; dan Allah Maha Luas (rahmatNya dan pengurniaanNya), lagi meliputi ilmuNya".

Menariknya dalam ayat ini, ia menjelaskan tentang kelayakan untuk menjadi raja atau pemimpin. Perkara paling utama yang ditekankan ialah seseorang itu perlu mempunyai kualiti dan ciri yang menepati fungsi seorang pemimpin. Justeru ia bukanlah sesuatu yang diwarisi disebabkan berketurunan nabi atau raja, malah bukan juga mempunyai harta kekayaan. Ciri yang 
melayakkan itu adalah ketinggian ilmu pengetahuan dan kesihatan fizikal $^{20}$.

Kesimpulannya, pemimpin dalam empat pemakaian istilah di atas menunjukkan fungsi seorang pemimpin seperti penganti kepada penguasa yang sebenar iaitu Allah dalam memakmurkan bumi, pemimpin dalam pelbagai sektor bidang ilmu dan agama, pemimpin yang berperibadi mulia dengan menunjukkan teladan yang baik seperti dalam mengerjakan kebajikan, mendirikan solat, menunaikan zakat, mencegah kemungkaran yang mana ia boleh diikuti oleh pengikutnya serta mempunyai kelebihan dari sudut ketinggian ilmu pengetahuan dan kesempurnaan anggota badan dan pancaindera.

Tambahan pula, Rasulullah pernah mengisyaratkan betapa pentingnya kehidupan perlu diurus melalui kewujudan seorang yang boleh memandu orang lain mencapai suatu keputusan dengan teratur. Dalam hal sekecil 3 orang bilangan musafir, Rasulullah arahkan "...maka hendaklah salah seorang dari kamu menjadi pemimpin”. Sebagaimana sabda baginda yang diriwayatkan oleh Abī Sa ‘īd al-Khudrī:

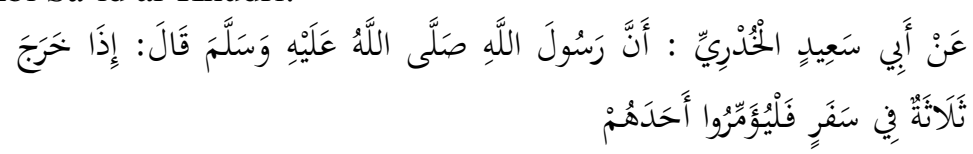

Logiknya sebagaimana al-Syawkānī nyatakan ia boleh mengelak timbulnya perselisihan yang membawa kepada kebinasaan (al-Talaf). Ini kerana jika tiada seorang yang dijadikan ketua bagi membuat kata putus, maka setiap pihak hanya akan menurut pendapatnya sahaja hingga boleh mencetuskan natijah yang buruk ${ }^{21}$.

Walau bagaimana pun pemimpin yang dipilih mestilah dari kalangan yang boleh diharapkan. Ini kerana keputusan yang diputuskan boleh menentu hala tuju kehidupan orang di bawahnya. Hal ini diungkap oleh Rasullullah dengan sabdanya yang berbunyi:

\footnotetext{
${ }^{20}$ Al-Ṭabari, Jāmi' al-Bayān 'an Ta'wīl al-Qur'ān.

${ }^{21}$ Muhammad, A.A, Nayl al-Awțar Syarh Muntaqā al-Akhbar (Beirut: Dār AlMa'rifah, 1998), 709:8.
} 


$$
\begin{aligned}
& \text { أبي هريرة عن النبي صلى الله عليه وسلم قال إنما الإمام جنة يقاتل من ورائه } \\
& \text { ويتقى به فإن أمر بتقوى الله عز وجل وعدل كان له بله بذلك أجر وإن يأمر بغيره } \\
& \text { كان عليه منه } 22
\end{aligned}
$$

Di dalam hadith tersebut Rasulullah SAW memberi gambaran antara fungsi pemimpin itu adalah sebagai perisai (Junnah) yang memerangi musuh rakyatnya dan melindungi mereka. Jika pemimpin itu mengajak rakyatnya kepada ketaqwaan kepada Allah dan bersikap adil maka pemimpin itu bermanfaat bagi rakyat, tetapi jika dia memerintahkan selain itu maka pemimpin itu merupakan musibah bagi rakyatnya ${ }^{23}$.

Selari dengan kesan besar yang boleh tercetus dari pengurusan kepimpinan, maka ada keperluan bagi mengkaji konsep ini dengan lebih mendalam khususnya dalam konteks pengurusan organisasi. Ini kerana tanggungjawab ini perlu diletakkan kepada pihak yang sesuai dengan sifat-sifat yang sesuai juga. Ini adalah seperti yang disarankan oleh Ibn Taymiyyah iaitu jika terpaksa memilih, maka calon pilihan hendaklah diberikan kepada calon memilikki merit tertentu. Misalnya lelaki yang kuat dan berani sekalipun kurang beribadat lebih sesuai dicalonkan bagi jawatan dalam mengurus peperangan sekalipun ada calon yang baik amalan agama tetapi lemah dari segi kecekapan dan fizikalnya $^{24}$. Dalam konteks pengurusan dan pentadbiran organisasi hari ini yang berhadapan dengan pelbagai cabaran, maka pemimpin yang dilantik mestilah memilikki ciri-ciri kepimpinan yang unggul. Ini untuk memastikan segala program dan aktiviti yang dirancang dapat dilaksanakan secara berkesan dan dapat memacu organisasi menuju kepada kecemerlangan.

\section{Kepentingan Pemimpin dalam Organisasi}

Kajian kepimpinan mulai mengambil bentuk dan identiti pada awal kurun ke 20, dengan kemunculan dua aliran teori berhubung

${ }^{22}$ Hadith riwayat Muslim kitab al-Imārah: no hadith 1841.

23 A.H.M Muslim, "Sahih Muslim," Kitab al-Imārah, Bab al-Imām Junnah yuqatalu min waraihi wa yuttaqa bih, Hadis no. 1841 (Riyadh: Bayt al-Afkar al-Dawliyah, 1998), 769.

${ }^{24}$ Ibn Taymiyyah, al-Siyāsah al-Syar'iyyah fi Islah al-Ra'iy wa al-Ra'iyyah (Beirut: Dār al-Fikr al-Lubnani, 1992). 
dengan kepimpinan. Aliran pertama diusahakan oleh ahli-ahli sosiologi sementara aliran kedua dipelopori oleh ahli-ahli psikologi ${ }^{25}$. Istilah pemimpin dan kepimpinan membawa makna yang berbeza kepada pengkaji yang berbeza. Perkataan "kepimpinan" dalam sains pentadbiran kerap digunakan silih berganti dengan perkataan "pengurus".

Peranan kepimpinan adalah peranan dalam interaksi sosial ${ }^{26}$. Pemimpin organisasi yang mempunyai peribadi yang hebat akan mudah mendapat kepercayaan daripada pekerja dan dalam memimpin organisasi ${ }^{27}$. Kepimpinan merupakan keupayaan mempengaruhi, memotivasi, mengubah sikap dan tingkah laku orang bawahan supaya bersetuju untuk melaksanakan programprogram dan melakukan perubahan-perubahan ke arah pencapaian matlamat organisasi. ${ }^{28}$ Fleishman menerangkan, definisi kepimpinan ialah suatu usaha ke arah mempengaruhi individu melalui proses komunikasi ke arah mencapai matlamat atau beberapa matlamat yang dikehendakki olehnya ${ }^{29}$.

Kepimpinan juga adalah kebolehan seseorang pemimpin organisasi untuk mengenali keperluan dan melaksanakan perubahan, menentukan arah tuju, memotivasi, mengilham, membangun sumber manusia, berkomunikasi, membangunkan pasukan kerja, berkongsi membuat keputusan, berintegriti serta sebagai penasihat dan jurulatih kepada orang lain ${ }^{30}$.

Oleh itu, seorang pemimpin haruslah mempunyai perancangan yang jelas dalam menyusun dan mengatur ahli-ahli organisasi mengikut kemahiran yang dimiliki masing-masing. Para pemimpin juga perlu mengetahui dengan mendalam visi, misi dan matlamat organisasi, supaya pemimpin dapat mengarah hala tuju

${ }^{25}$ Aminuddin bin Mohd Yusof, Siri Analisis Psikologi Kepimpinan (Kuala Lumpur: Dewan Bahasa dan Pustaka, 1990), 2.

${ }^{26}$ Aminuddin, Siri Analisis Psikologi Kepimpinan, 4, t.h.

${ }^{27}$ Siti Arni, Bharudin dan Raja Hisyamudin, Suntikan Nilai-Nilai Islam, 108, t.h.

${ }^{28}$ Sarvinder Singh dan Ahmad bin Esa, "Kepimpinan dalam Menghadapi Isu-Isu Semasa Pendidikan" (Makalah, Seminar Kebangsaan Pengurusan Pendidikan Universiti Tun Hussein Onn Malaysia, 16 Oktober 2008), 1.

${ }^{29}$ Daniel Katz dan Robert. L Khan, The social psychology of organization (New York: John Wiley. 1966), 300-301.

${ }^{30}$ Noraini Misran dan Ahmad Othman, "Hubungan Ciri-Ciri Kepimpinan Berorientasikan Pekerja Terhadap Kejayaan Projek di Kalangan Kontraktor dalam Industri Pembinaan", (International Conference on Management, Kuala Lumpur, 3 Mac 2011), 871. 
dan gerak kerja ahli organisasi kearah pencapaian matlamat yang ditetapkan.

Daripada definisi-definisi yang diperkatakan oleh para sarjana barat, dapat disimpulkan bahawa kepimpinan menggambarkan ciri atau sifat seseorang pemimpin yang mampu untuk mempengaruhi orang lain dengan baik dan beretika, kepimpinannya tersusun rapi, bermatlamat dan berwawasan, dapat membantu rakyat dan dapat mempengaruhi pengikut supaya melaksanakan segala perintahnya walaupun terdapat beberapa perintah itu yang tidak disenangi oleh pengikutnya.

Islam sendiri amat mementingkan kepimpinan. Ini seperti yang dinyatakan dalam hadis di bawah ini:

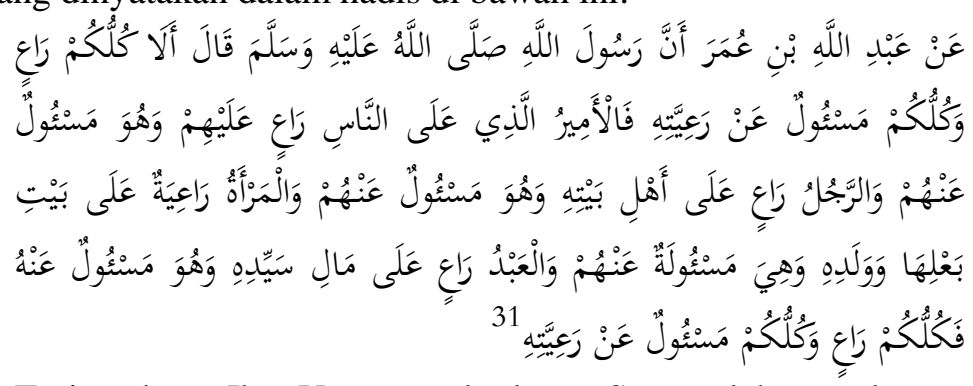

Terjemahan: Ibn Umar r.a berkata: Saya telah mendengar Rasulullah SAW bersabda : Setiap orang adalah pemimpin dan akan diminta bertanggugjawab atas kepemimpinannnya. Seorang ketua negara akan diminta bertanggugjawab akan rakyat yang dipimpinnya. Seorang suami akan ditanya perihal keluarga yang dipimpinnya. Seorang isteri yang memelihara rumah tangga suaminya akan ditanya perihal tanggungjawab dan tugasnya. Bahkan seorang pembantu/pekerja rumah tangga yang bertugas memelihara barang milik majikannya juga akan ditanya dari hal yang dipimpinnya. Dan kamu sekalian pemimpin dan akan ditanya (diminta bertanggugjawab) tentang hal yang dipimpinnya.

Hadis tersebut menunjukkan bahawa setiap orang adalah pemimpin dan setiap pemimpin bertanggungjawab terhadap orang yang dipimpinnya. Kata-kata ini tentulah diucap dengan kesedaran bahawa kepimpinan adalah proses harian yang berlaku apabila saja

${ }^{31}$ Hadith riwayat al-Bukhārī, kitāb al-Jum'ah, no hadith 853 dan hadith riwayat Muslim kitāb al-Imārah, no hadith 1829. 
terdapat dua orang atau lebih berkumpul. Kepimpinan berlaku baik dalam sebuah keluarga yang kecil yang mengandungi ibu bapa dan anak mahupun dalam sebuah negara ${ }^{32}$.

Para nabi ditugaskan Allah untuk menyampaikan risalah Allah kepada manusia demi memastikan islam itu terlaksana di atas muka bumi ini. Samalah seperti konsep pemimpin di dalam sesebuah organisasi iaitu memimpin kakitangannya supaya tidak melakukan kesalahan yang melanggar peraturan organisasi dan seterusnya memimpin mereka ke arah yang lebih baik dan sistematik $^{33}$.

Justeru itu, banyak pandangan mengenai kepentingan kepimpinan sama ada yang bersetuju atau tidak. Walaupun apa yang diperkatakan kebanyakan orang bersetuju bahawa pemimpin tetap dikehendaki seperti pandangan dari Katz dan Kahn yang mengemukakan lima faktor kepentingan kepimpinan dalam organisasi, sama ada organisasi yang besar atau pun $\mathrm{kecil}^{34}$ :

1) reka bentuk organisasi yang tidak lengkap

2) kepimpinan sebagai fungsi sempadan

3) keadaan persekitaran yang sentiasa berubah

4) dinamik dalaman organisasi

5) tabii keanggotaan manusia dalam organisasi

Oleh kerana setiap individu Muslim dibebani dengan tanggungjawab memimpin, mereka dibekalkan oleh Allah SWT dengan potensi kepimpinan yang boleh dikembangkan. Setiap muslim mempunyai potensi tersendiri untuk menjadi seorang pemimpin yang berkesan dalam lingkungan tanggungjawab masing-masing. Ini kerana kepimpinan bukanlah statik atau kaku dan tidak berkembang tetapi ia sebenarnya dinamik, boleh berubah kepada tahap yang lebih baik dengan melalui beberapa proses tertentu. Wujud sesetengah penulis yang beranggapan seorang pemimpin berpengaruh memang telah dilahirkan dengan beberapa

32 Abū Abd allāh Muḥammad Ismā‘̄il al-Bukhārī, "Sahih al-Bukhari," Kitab al'Itqu, Bāab al-'Abd Ra'in fĩ ma lā Saidihi, no.Hadith 2558 (Kaherah: Maktabah al-Salafiyyah, 1982), 222.

${ }^{33}$ Lokman bin Abdul Rasol, Pengurusan Kualiti Menurut Perspektif Islam: Kajian di Majlis Perbandaran Subang Jaya (Disertasi, Universiti Malaya, 2013), 66.

${ }^{34}$ Baharom bin Mohamad, Mohamad Johdi bin Salleh dan Che Noraini binti Hashim, "Kepimpinan Pendidikan Berkesan", (Kertas kerja, Seminar ke-4 Kepengetuaan Kebangsaan, Universiti Malaya, 12 Mac 2009), 2. 
sifat yang melayakkan dirinya sebagai pemimpin. Dengan erti kata lain mereka born to be are leader atau memang mereka dilahirkan untuk menjadi pemimpin.

Bagaimanapun, pemimpin yang berpengaruh diakui perlu juga melalui beberapa proses atau latihan yang boleh membentuk personalitinya sebagai seorang pemimpin yang berjaya. Seorang pemimpin yang mencurahkan seluruh pemikiran dan tenaganya bagi memastikan pengikut-pengikut memperolehi manfaat yang banyak dari kepimpinannya dijanjikan oleh Allah SWT dengan ganjaran yang besar.

Pemimpin atau pengurusan atasan adalah mereka yang memikul tanggungjawab. Tanggungjawab bagi menegakkan seruan Islam di bumi dengan mengikut jejak pemimpin yang menunjukkan rekod cemerlang. Dari sini boleh dilihat, tanggungjawab pengurusan atasan amatlah besar dan berat.

Di samping itu, umat Islam digesa supaya sentiasa penuh sedar tentang keperluan dan kepentingan kepimpinan. Kepimpinan yang cemerlang akan melahirkan masyarakat yang cemerlang. Kepimpinan dari perspektif Islam tidaklah semata-mata merujuk kepada pemimpin di peringkat negara, tetapi juga pemimpin di peringkat organisasi. Pemimpin organisasi perlu memainkan peranan secara efektif untuk menjayakan pelbagai program yang diatur. Banyak program pengurusan yang digunapakai di organisasi masa kini seperti program kualiti, perancangan strategik, petunjuk prestasi utama, penanda aras dan etika kerja Islam.

\section{Etika Kerja Islam}

Etika kerja Islam mempunyai pelbagai dimensi yang berkaitan dengan pelbagai aspek kehidupan seperti sosial, politik dan ekonomi. Etika kerja Islam boleh ditakrifkan sebagai satu set nilai atau sistem kepercayaan yang berasal dari al-Quran dan Sunnah mengenai kerja dan kerja keras ${ }^{35}$. Etika Kerja Islam orientasi ke

${ }^{35}$ Shukri bin Ahmad dan Musa Yusuf Owoyemi, "The Concept of Islamic Work Ethic: An Analysis of Some Salient Points in the Prophetic Tradition", International Journal of Business and Social Science 3, no 20 (2012), 118. 
arah kerja yang berakar umbi berasaskan prinsip-prinsip Syariah Islam $^{36}$.

Etika kerja menurut Islam merupakan suatu tanggungjawab kepada setiap pemimpin untuk mematuhinya dan menjadi rutin yang wajib diamalkan selagi mana dipertanggungjawabkan kepadanya akan peranan kepemimpinan. Ianya juga memberi panduan kepada setiap pemimpin supaya lebih berdedikasi dalam memimpin serta akan menghasilkan pemimpin yang mampu menunaikan tanggungjawabnya dengan berkesan.

Etika kerja Islam yang bertunjangkan keimanan kepada Allah menjadikan individu lebih beramanah dan bertanggungjawab dalam melaksanakan tugasannya. Pengamalan prinsip bekerja untuk mendapatkan keredaan Allah SWT, amanah, tanggungjawab, bersungguh-sungguh, menepati masa, syura dan mesyuarat serta komunikasi yang baik mampu menjadi pemangkin kepada pembangunan organisasi yang efisien. Kepentingan kepimpinan berfungsi sebagai kunci kepada kejayaan organisasi ${ }^{37}$. Tambahan pula, dengan kehidupan dunia global yang penuh dengan cabaran, menggugat ketahanan dan keimanan para pemimpin Islam, sudah tentu etika menurut Islam dilihat sangat perlu demi melahirkan kepimpinan yang unggul, cekap, bersih, dan amanah. Selain itu, ia juga dapat mengelakkan diri pemimpin dari kegiatan salah laku yang ada pada hari ini. Kamal (1998) dan Shukri dan Musa Yusuf (2012) ${ }^{38}$ telah menyenaraikan lima sifatsifat etika kerja Islam seperti berikut:

i. Melakukan pekerjaan untuk mendapat keredaan Allah

ii. Amanah

iii. Ganjaran

iv. Keadilan

v. Hubungan majikan dan pekerja yang harmoni

\footnotetext{
${ }^{36}$ Mohamed Farah Abdi, Siti Fatimah binti Wira Muhamad Nor dan Nor Zuhairatun binti Md. Radzi, "The Impact of Islamic Work Ethics on Job Performance and Organizational Commitment", (Paper, Asia-Pacific Business Research Conference, Kuala Lumpur, 17-18 February 2014), 1.

${ }^{37}$ Noraini dan Ahmad, Hubungan Ciri-Cciri Kepimpinan, 878, t.h.

${ }^{38}$ Shukri dan Musa, The Concept, 118, t.h.
} 


\section{Peranan Pemimpin dalam Pelaksanaan Etika Kerja Islam}

Literatur menunjukkan pemimpin mempunyai peranan tertentu yang boleh dimainkan untuk memastikan kelancaran pelaksanaan etika kerja Islam di tempat kerja. Peranan yang boleh dimainkan adalah seperti berikut:

\section{i. Komunikasi}

Komunikasi di dalam sesebuah organisasi adalah bertujuan untuk menyampaikan maklumat yang benar dan tepat kepada ahli-ahli berkenaan dengan perkara-perkara penting tentang tugasan dan matlamat yang ingin dicapai. Pemimpin yang memilikki kemahiran komunikasi dan interpersonal yang hebat sudah pasti dapat mengurus pekerja dengan lebih berkesan. Komunikasi antara pihak pengurusan dan pekerja menjadi perkara utama yang perlu diberi perhatian oleh mana-mana pengurusan organisas ${ }^{39}$. Pemimpin organisasi menghabiskan sebahagian besar masanya untuk berkomunikasi dengan pekerjanya. Maka, amat penting untuk pemimpin organisasi berkomunikasi dengan bijak agar perkara yang menjadi kandungan komunikasi dapat difahami dengan jelas oleh pekerjanya.

Etika kerja Islam perlu pemahaman yang jelas sebelum semua pihak dapat melaksanakannya dengan penuhi penghayatan. Dalam konteks inilah, etika kerja Islam memerlukan penjelasan yang mantap agar ahli-ahli dapat memahami dan menghayatinya. Oleh itu, pemimpin organisasi hendaklah bijak, kreatif dan bersungguh-sungguh dalam menjelaskan tentang pentingnya etika kerja Islam untuk difahami dan seterusnya dilaksanakan.

\section{ii. Latihan}

Okland $(1995)^{40}$ menyatakan bahawa latihan adalah usaha yang dirancang oleh sesebuah organisasi untuk memudahkan pembelajaran warga kerja berkaitan dengan keperluan dan prosedur kerja. Antara keperluan-keperluannya adalah berkaitan dengan pengetahuan, kemahiran dan tingkah laku supaya pekerja dapat menjalankan tugas dengan lebih efektif. Russell dan Stone

\footnotetext{
${ }^{39}$ Siti Arni, Bharudin dan Raja Hisyamudin, Suntikan Nilai-nilai Islam, 108 t.h.

40 Thomas Oakland, "The Bell Curve: Some Implication The Discipline of School Psychology and Practices of School Psychology," School Psychology Review 24, no 1 (1995), 20-26.
} 
(2002) menjelaskan bahawa pemimpin berorientasikan pekerja mempunyai kuasa untuk melatih dan membangunkan orang lain. ${ }^{41}$

Pemimpin mempunyai komitmen untuk membangunkan potensi pekerja bagi mengembangkan kemahiran, personaliti dan profesionalisme mereka di samping mewujudkan pasukan kerja yang efektif dan efisien. Menurut Noraini dan Ahmad (2011) ${ }^{42}$, dengan membangunkan pekerja yang berkesan boleh mempengaruhi pencapaian matlamat dan kejayaan sesebuah organisasi. Latihan sangat penting untuk memberi kefahaman tentang etika kerja Islam kepada warga kerja. Kefahaman pula akan mendorong mereka untuk mengamalkan etika kerja Islam dalam kerja-kerja seharian mereka.

\section{iii. Persekitaran}

Pemimpin juga mestilah mencipta dan mempertahankan persekitaran organisasi bagi membolehkan semua warga kerja melibatkan diri secara aktif dalam usaha untuk mencapai matlamat organisasi $^{43}$. Islam memberi perhatian berat terhadap aspek kepimpinan termasuklah ciri-ciri, pendekatan yang diamalkan oleh pemimpin dan juga faktor persekitaran yang mempengaruhi gaya kepimpinan.

Persekitaran yang baik amat penting dalam sesebuah organisasi kerana dengan adanya dengan wujudnya suasana tersebut akan memudahkan lagi pengurusan dan perjalanan aktiviti sesebuah organisasi serta menjamin keberhasilan sesuatu kerja. Pemimpin berorientasikan pekerja akan mewujudkan persekitaran di mana setiap pekerja boleh mencapai potensi mereka ke arah pencapaian matlamat organisasi ${ }^{44}$. Persekitaran yang selesa dan sesuai penting untuk pelaksanaan etika kerja Islam. Oleh itu, pemimpin haruslah menunjukkan sikap dan komitmen yang mampu mendorong suasana bekerjasama untuk memudahkan perlaksanaan etika kerja Islam di tempat kerja.

\footnotetext{
${ }^{41}$ Robert F.Russell and A.Gregory Stone, "A Review of Servant Leadership Attributes: Developing a Practical Model”, Leadership and Organization Development Journal 23, no 3 (2002), 145-157.

${ }^{42}$ Noraini dan Ahmad, Hubungan Ciri-ciri Kepimpinan, 878, t.h..

${ }^{43}$ Siti Arni, Bharudin dan Raja Hisyamudin, Suntikan Nilai-Nilai Islam, 106, t.h.

${ }^{44}$ Noraini dan Ahmad, Hubungan Ciri-ciri Kepimpinan, 877, t.h.
} 


\section{iv. Sistem ganjaran}

Menurut Autry (1991) ${ }^{45}$, kepimpinan bukan sahaja mengawal orang lain, tetapi juga mengambil berat akan orang lain dan menjadi satu sumber rujukan yang bermakna kepada mereka. Pemimpin juga perlu mengagihkan sumber organisasi dengan efektif kerana perjalanan operasi dan pentadbiran amat memerlukan peruntukan dana yang mencukupi. Antara aspek yang perlu diberi perhatian pemimpin organisasi ialah aspek ganjaran kerana ia bukan hanya perlu untuk membiayai kehidupan pekerja, tetapi juga ia adalah alat atau mekanisme penting untuk menghargai dan memotivasikan mereka. Ganjaran asas berbentuk gaji, kemudahan untuk cuti, kemudahan perubatan dan kemudahan pinjaman kewangan.

Pekerja yang mengamalkan etika kerja Islam hendaklah diberi pujian dan ganjaran, manakala pekerja yang melanggar etika kerja Islam hendaklah diberi amaran atau diambil tindakan. Pemimpin hendaklah menyediakan mekanisme yang jelas untuk mendorong perlakuan yang patuh kepada etika kerja Islam. Ini kerana kepatuhan kepada etika Islam mampu menjadi contoh ikutan kepada warga kerja lain untuk mengamalkan sifat-sifat unggul di tempat kerja seperti amanah, disiplin, bersungguh-sungguh, mementingkan kecemerlangan dan musyawarah.

\section{v. Motivasi}

Pemimpin mempengaruhi individu dengan memotivasikan pengikutnya ke arah melakukan yang terbaik dalam tugas ${ }^{46}$. Tambahan pula dengan mengamalkan etika kerja Islam akan dapat meningkatkan komitmen organisasi dan tahap motivasi kerja ${ }^{47}$. Sehubungan dengan ini, Bayyumi melihat semangat motivasi Islam yang diasaskan daripada unsur kerohanian merupakan faktor utama dalam menentukan kejayaan. Motivasi adalah sangat penting dalam kerja-kerja seorang Muslim, namun ia tidak boleh

${ }^{45}$ James A Autry, Love and Profit: The Art of Caring Leadership (New York: Avon Books, 1991).

${ }^{46}$ Suraiya binti Ishak, "Model Kepemimpinan Etika Berlandas Sirah Nabi Muhammad SAW)", Jurnal Hadhari 3, no 2 (2011), 27.

${ }^{47}$ Muhammad Shakil bin Ahmad, "Work Ethics: an Islamic Prospective", International Journal Of Human Sciences 8, no 1 (2011), 850. 
membawa kepada kerja-kerja yang berlebihan sehingga menjejaskan kewajipan agama dan sosial.

Etika kerja Islam yang diamalkan di sektor kerajaan atau swasta memerlukan suntikan motivasi daripada kepimpinan organisasi. Oleh itu, pemimpin organisasi mestilah bijak memainkan peranan untuk memotivasikan pegawai dan pekerja dalam usaha untuk melaksanakan etika kerja Islam secara tuntas.

\section{vi. Pembuatan Keputusan}

Tugas-tugas membuat keputusan merupakan agenda utama kepemimpinan. Dalam membuat keputusan berkenaan dengan pelaksanakan etika kerja Islam, bukanlah merupakan perkara yang mudah. Oleh itu, seseorang pemimpin itu perlu berani dan bijak dalam mengambil dan melaksanakan sesuatu keputusan. Seorang pemimpin perlu berfungsi sebagai model kepada amalan-amalan beretika dalam organisasi, memberi ganjaran dan hukuman bagi menguatkuasakan perlakuan dikehendakki atau membendung perlakuan tidak dikehendakki dan mewar-warkan etika dan nilainilai kepada seluruh ahli organisasi melalui program tertentu. ${ }^{48}$

Dalam pelaksanaan etika kerja Islam, kepimpinan mengambil kira pelbagai faktor dalam membuat keputusan, membawa pekerja ke arah pencapaian matlamat organisasi dan mempunyai rasa bertanggungjawab kepada sebarang perlakuan atau tindakan yang telah dilaksanakan ${ }^{49}$. Seorang pemimpin hendaklah membuat keputusan-keputusan yang menyokong kepada pelaksanaan etika kerja Islam. Ianya boleh dilakukan dengan menyediakan mekanisme, peraturan, ganjaran dan hukuman yang akan memperkukuhkan lagi amalan etika kerja Islam di tempat kerja.

\section{vii. Memantau}

Setiap kerja yang dilakukan haruslah dipantau dan diberikan garis panduan tentang bagaimana ianya patut dilaksanakan. Sesebuah organisasi yang baik perlu mempunyai stuktur organisasi yang kemas dan tersusun. Bagi memastikan setiap tugas dilakukan dengan sempurna, pemantauan daripada pihak atasan adalah perlu

\footnotetext{
${ }^{48}$ Suraiya, Model Kepemimpinan Etika, 29, t.h.

${ }^{49}$ Lokman bin Mohd Tahir dan Hamidon binti Abdul Rahman, "Peranan Etika dalam Kepimpinan Pendidikan", Jurnal Pendidikan Universiti Teknologi Malaysia 8 (2002), 100.
} 
dan setiap arahan yang diberikan perlu dilaksanakan dengan sebaiknya ${ }^{50}$. Pemantauan merupakan instrumen penting untuk tujuan pengawalan status dan prestasi tugasan atau program yang telah ditetapkan. Pemimpin yang sering melakukan pemantauan dapat memberikan sesuatu arahan, nasihat dan keputusan yang berkesan kepada pekerja dalam pelaksanaan etika kerja Islam $^{51}$. Contohnya pegawai menasihati pekerja yang suka datang lewat dan bukannya terus mengambil tindakan memarahi atau membuang pekerja tersebut. Namun begitu, mereka terlebih dahulu hendaklah dilatih untuk memahami masalah atau konflik yang dihadapi dalam sesebuah orgnisasi. Ini bertepatan dengan sabda Nabi Muhammad SAW yang bermaksud "Agama itu suatu nasihat". 52

Seperti mana program-program pengurusan yang lain, pelaksanaan etika kerja Islam juga memerlukan pemantauan. Semua pihak dalam organisasi perlu diperhati dan dipantau untuk mengetahui sejauh mana komitmen mereka untuk melaksanakan etika kerja Islam. Pemimpin atau pengurusan tertinggi organisasi juga perlu mengawasi jika terdapat sebarang kelemahan atau masalah dalam pelaksanaan etika kerja Islam dan berusaha untuk mengatasi masalah tersebut.

\section{Metodologi}

Kajian ini menggunakan pendekatan kualitatif, dengan kajian kes digunakan sebagai strategi kajian seperti yang dicadangkan oleh Yin (2014). Organisasi yang dipilih sebagai kajian kes ialah JCorp, iaitu sebuah syarikat korporat yang yang tersohor di Malaysia.

Sumber utama data untuk kajian ini ialah sumber yang berbentuk dokumen. Yin (2014) ${ }^{53}$ menegaskan bahawa antara sumber data yang digunakan dalam kajian kes ialah dokumen. Dokumen utama yang

${ }^{50}$ Mohamed Sulaiman, Nur Arfifah binti Abdul Sabian and Abdul Kadir bin Othman, "The Understanding of Islamic Management Practices Among Muslim Managers in Malaysia", Asian Social Science 10, no 1 (2014), 189199.

${ }^{51}$ Sharifah Hayaati binti Syed Ismail al-Qudsy dan Mohd Mauli bin Abu Bakar, "Etika Penyelesaian Konflik dalam Pentadbiran Islam: Suatu Perbandingan", Jurnal Syariah 14, no 1 (2006), 16.

52 Sharifah Hayaati dan Mohd Mauli bin Abu Bakar, Etika Penyelesaian Konflik dalam Pentadbiran Islam, 18, t.h.

${ }^{53}$ Yin, R.K., Case Study Research. $3^{\text {rd }}$ ed. (t.tp.: Sage Publications 2014). 
digunakan sebagai sumber data ialah Laporan Tahunan JCorp bagi tahun 2013 dan 2014. Laporan tersebut mengandungi pelbagai fakta dan informasi lengkap berkaitan dengan dasar, aktiviti, program, status dan pencapaian JCorp. Sumber data lain ialah buku yang bertajuk 'Khalifah Ganti Superman', karangan mantan Ketua Pegawai Eksekutif JCorp, iaitu Mohd. Ali Hashim yang diterbitkan pada 2013. Buku tersebut merupakan kompilasi tulisan Mohd. Ali dalam media massa semenjak beberapa tahun kebelakangan ini. Antara kandungan utama buku tersebut menceritakan secara komprehensif mengenai pengalaman Mohd. Ali semasa beliau bersama JCorp selama lebih 30 tahun. Kebanyakan dasar, program dan sistem pengurusan yang diputuskan beliau semasa menjadi peneraju JCorp masih dilaksanakan sehingga kini. Selain itu, rencanarencana terkini tulisan Mohd. Ali yang diterbitkan di media massa turut digunakan sebagai sumber data alam kajian ini. Laporan Tahunan JCorp, buku Khalifah Ganti Superman dan rencana-rencana di media massa tersebut menunjukkan kandungan maklumat yang banyak mengenai JCorp, dan ditulis dengan terperinci. Oleh kerana maklumat tersebut bersifat terperinci dan naratif, maka ianya membolehkan analisis secara mendalam dilakukan untuk menyelidikki tentang peranan pemimpin dalam pelaksanaan etika kerja Islam di JCorp.

Braun dan Clark (2006) ${ }^{54}$ telah menyarankan kaedah analisis tema (thematic analysis) sebagai kaedah analisis data untuk kajian kualitatif. Kaedah ini digunakan dalam kajian ini, iaitu dengan mengambil beberapa langkah seperti yang dicadangkan iaitu memahami data yang dikumpulkan, mencipta kod, membina tema dan menulis laporan hasil kajian. Melalui kaedah ini, tema-tema mengenai peranan pemimpin dalam pelaksanaan etika kerja Islam di JCorp telah ditemui dan dibincangkan secara menyeluruh.

\section{Latar Belakang Jcorp}

JCorp merupakan sebuah badan korporat yang dikenali di Malaysia sebagai sebuah entiti yang memiliki empayar perniagaan yang besar. Sejarah syarikat ini bermula pada tahun 1968 apabila Kerajaan Johor menubuhkan Perbadanan Kemajuan Ekonomi Negeri Johor (PKENJ) ataupun turut dikenali sebagai Johor State Economic Development

\footnotetext{
${ }^{54}$ V. Braun, and V Clarke, "Using Thematic Analysis in Psychology", Qualitative Research in Psychology 3 (2006), 77-101.
} 
Corporation (JSEDC) di bawah Rancangan Malaysia ke 4 pada tahun 1968. Badan ini ditubuhkan sebagai sebuah perusahaan awam dan badan berkanun melalui Enakmen Johor No. 4/1968 (pindaan sebagaimana Enakmen No. 5/1995). PKENJ telah memulakan operasi pada 1 Ogos 1970 dengan modal pelaburan sebanyak 10 juta ringgit yang dipinjamkan oleh Kerajaan Negeri Johor. Perbadanan ini memulakan bisnes dengan menjadikan pengurusan Ladang Tebrau seluas 1,580 hektar sebagai aktiviti pertama. Penglibatan dalam aktiviti pertanian ini disebabkan oleh kepakaran Tan Sri Dato' Haji Basir Bin Ismail dalam menguruskan bidang pertanian dan lebih sesuai dilakukan pada ketika itu ${ }^{55}$.

Nama PKENJ ini kemudiannya ditukar kepada Perbadanan Johor atau lebih dikenali sebagai Johor Corporation (JCorp) pada tahun 1995. Sebagai sebuah entiti perusahaan awam, JCorp telah memainkan peranan yang besar dalam melancarkan dan merangsang pertumbuhan ekonomi di negeri Johor, khususnya di beberapa sektor ekonomi yang berpotensi tinggi, termasuklah perusahaan pertanian, pemajuan perindustrian, pemajuan hartanah dan sebagainya. Kini JCorp memiliki cawangan dalam bidang perniagaan meliputi bisnes sawit (Kulim), Perkhidmatan Kesihatan Pakar (prisihatin) \& kesihatan, makanan \& perkhidmatan restoran segera, hartanah, khidmat sokongan dan perlaburan, hospitaliti, bisnes keushawanan, minyak dan gas serta bisnes baru.

Setelah lebih 43 tahun ditubuhkan, JCorp sebagai sebuah entiti bisnes pacuan pasaran kini memberi fokus untuk merealisasikan matlamat yang digariskan dalam pelan transformasi strategik bisnesnya, dan pada masa sama mengimbangi obligasi dan komitmennya. JCorp telah menterjemahkan keupayaan dengan mengekalkan prestasi kewangan dan korporat yang cemerlang di sebalik ketidaktentuan ekonomi global. Sebaliknya, dengan asas bisnes yang kukuh, keupayaan modal insannya, pematuhan etika korporat dan amalan nilai-nilai murni, serta berhemah dan berstrategi, JCorp terus melebarkan sayap pasaran sambil menceburi bisnes baharu demi meneruskan peranan sebagai agen pembangunan negeri dan melaksanakan tanggungjawab korporatnya. Pelbagai program

55 JCorp, Laporan Tahunan JCorp (Johor Bahru, Johor, Malaysia. Jabatan Penerbitan JCorp. 2013, 2014). 
tanggungjawab korporat telah dilaksanakan yang antaranya ialah Kulim Wildlife Defenders, Waqaf An-Nur, Rangkaian Masjid AnNur, Briged Waqaf, Tabung Tijarah Ramadan, Hospital dan Klinik Waqaf An-Nur, Program Keusahawanan Bistari dan Projek Tuisyen $^{56}$.

Johor Corporation (JCorp) telah menunjukkan prestasi membanggakan dengan mencatatkan keputusan kewangan bagi tahun 2013 dengan peningkatan keuntungan sebelum cukai sebanyak dua kali ganda kepada RM1.37 bilion, melepasi paras RM1 bilion (Utusan Malaysia, 2014). Pada 2014, JCorp telah memenangi The Brandlaureate BillionDollarBrand 2014-2015, iaitu jenama terulung peringkat Asia Pasifik. Pengiktirafan tersebut adalh berdasarkan prestasi kewangan cemerlang JCorp yang mencatat perolehan hampir RM7 bilion dan keuntungan sebelum cukai berjumlah lebih RM1 bilion pada tahun kewangan yang lalu. JCorp memilikki 265 syarikat aktif di dalam kumpulan dengan jenama terkenal; antaranya ialah KFC dan Pizza Hut Malaysia, KPJ Healthcare Berhad, Kulim (Malaysia) Berhad dan Johor Land Berhad yang meneraju pelbagai sektor di negeri Johor khasnya dan Malaysia amnya. Untuk bisnes di luar negara pula, JCorp berjaya bertapak di Indonesia, Singapura, Brunei, Kemboja, Thailand, Bangladesh, India dan Australia. Pencapaian tersebut telah melayakkan JCorp untuk merangkul anugerah antarabangsa tersebut anjuran Yayasan Jenama Asia Pasifik (APBF). Anugerah tersebut merupakan itu satu pengiktirafan antarabangsa kepada kekukuhan jenama sesebuah konglomerat berdasarkan kepada spektrum penjenamaan yang berjaya di peringkat kumpulan ${ }^{57}$.

\section{Hasil Kajian dan Perbincangan}

Hasil kajian menunjukkan terdapat enam peranan pemimpin dalam pelaksanaan etika kerja Islam di JCorp. Enam peranan tersebut dibincangkan seperti berikut:

\footnotetext{
${ }^{56}$ JCorp, Laporan Tahunan JCorp, t.h.

${ }^{57}$ Utusan Malaysia, “JCorp Jenama Terulung," dicapai 11 September 2015, http://www.utusan.com.my/berita/nasional/jcorp-jenama-terulung-1.58618.
} 


\section{Peranan Pemimpin dalam Pelaksanaan Etika Kerja Islam di JCorp}

\section{Latihan}

JCorp amat mementingkan program-program latihan dalam usaha untuk melahirkan modal insan yang cemerlang. Misalnya dengan mengadakan siri program latihan dan kursus untuk meningkatkan ilmu pengetahuan, mengaplikasi sistem dan formula terkini dalam kerja dan pentadbiran. Anggota pekerja JCorp yang terpilih juga diberi peluang memperkasakan bakat, kepemimpinan dan meningkatkan kerjaya bagi memastikan JCorp memilikki pelapis berwibawa untuk meneruskan visi dan misi. Antaranya melalui program tahunan termasuk Johor Corporation Leadership Programme dan Johor Corporation Directors Conference. Pada masa sama, anggota pekerja turut didedahkan dengan program pemupukan sahsiah dan penyuburan integriti selain bertujuan meningkatkan ketahanan fizikal dan mental, mengeratkan kerjasama dan semangat berpasukan serta menggilap kecekapan membuat keputusan ${ }^{58}$.

Program latihan dan pembangunan modal insan bukan hanya bertujuan untuk melahirkan warga kerja yang berkemahiran tinggi, tetapi juga bertujuan untuk melahirkan modal insan yang memilikki keperibadian mulia. Ini seperti yang ditegaskan oleh Mohd. Ali iaitu mantan Ketua Pegawai Eksekutif JCorp yang menekankan bahawa JCorp sentiasa menjalankan kursus bina insan dan penerapan budaya yang selari dengan kehendak Islam. Mohd Ali juga mempunyai pendirian bahawa mana-mana organisasi jangan terlalu mengharapkan pihak luar termasuk pihak kerajaan untuk memperkasakan keperibadian pekerja. Dalam konteks ini beliau berkata seperti berikut (Mohd. Ali, 2013; hal. $366)^{59}$ :

"Paling penting, syarikat atau organisasi jangan sekali-kali mengharapkan pihak ketiga atau pihak luar termasuk kerajaan untuk menerapkan amanah dan memperkasa iman. JCorp sentiasa menjalankan kursus bina insan dan penerapan budaya serta amalan yang berlandaskan Islam dalam kalangan anggota pekerjanya. Setelah itu, barulah JCorp

58 JCorp, Laporan Tahunan JCorp, 2013, 2014).

59 Mohd Ali bin Hashim, "Khalifah Ganti Superman" (Kuala Lumpur: Utusan Publications \& Distributers. 2013). 
bersedia untuk bertawakal seperti yang dianjurkan oleh Islam".

Komitmen pemimpin terhadap pembangunan pekerja terbukti apabila JCorp menganjurkan Program Mukmin Profesional pada 2014 yang bertujuan melahirkan anggota pekerja berketrampilan dan berintregriti ke arah menjadi pemangkin budaya kerja lebih produktif serta menjadi penggerak agama dan bangsa. Program ini melibatkan semua kategori anggota pekerja termasuk kumpulan pengurusan atasan. Program ini selari dengan tradisi JCorp yang mementingkan budaya keilmuan ${ }^{60}$. Manakala pemupukan sahsiah dan akhlak pula dilakukan dengan menggalakkan anggota pekerja solat berjemaah di surau pejabat dan masjid kelolaan JCorp, menganjurkan sesi ceramah dan tazkirah, menyertai majlis tahlil dan membaca Yassin dan bergotong-royong menjayakan ibadah korban $^{61}$.

Menurut Oakland $(1995)^{62}$, latihan adalah usaha yang dirancang oleh sesebuah organisasi untuk memudahkan pembelajaran warga kerja berkaitan dengan keperluan kerja. Hasil kajian menunjukkan latihan dan program pembangunan modal insan yang turut memberi penekanan kepada aspek kerohanian dan keagamaan telah melahirkan warga kerja JCorp yang mampu memahami dan menghayati ajaran Islam di tempat kerja. Penghayatan ini membina peribadi muslim yang seterusnya memberi kekuatan kepada mereka untuk mengamalkan etika kerja yang selari dengan kehendak Islam seperti amanah, kerjasama, tekun dan berdisiplin. Kepimpinan di JCorp menunjukkan komitmen yang tinggi dalam mengadakan latihan yang bersifat holistik yang bukan hanya mementingkan aspek kecekapan, tetapi juga aspek penghayatan terhadap ajaran Islam. Kepimpinan JCorp juga tidak bergantung kepada pihak luar, sebaliknya memberi penekanan kepada latihan dalaman yang dijalankan oleh organisasi itu sendiri. Pendekatan tersebut merupakan pendekatan yang efektif dalam usaha membina warga kerja yang berkemahiran tinggi dan memiliki sahsiah yang baik.

\footnotetext{
${ }^{60}$ JCorp, Laporan Tahunan JCorp (Johor Bahru: Jabatan Penerbitan JCorp. 2014, 2015).

61 JCorp, Laporan Tahunan JCorp, t.h.

62 Thomas Oakland, The Bell Curve, 20-26, t.h.
} 


\section{Komunikasi}

JCorp sebagai sebuah organisasi korporat amat mementingkan komunikasi dan musyawarah antara pihak atasan dan seluruh warga kerja JCorp. Menurut Mohd Ali, Persidangan Dialog dan Amanat (PEDOMAN) yang diamalkan semenjak lebih 20 tahun misalnya, adalah untuk bermusyawarah mengenai segala isu dan halatuju yang akan dihadapi oleh JCorp pada sesuatu tahun tertentu. Ia adalah sistem syura seperti yg disarankan Islam ${ }^{63}$. Pada persidangan tersebut, setiap warga kerja baru pelbagai peringkat diberi peluang untuk memperkenalkan diri masing-masing. Walaupun sesi tersebut memakan masa, tetapi ia dianggap penting dan bermakna bagi JCorp; ia menepati falsafah JCorp yang tegas dengan pendirian bahawa setiap anggota adalah penting untuk masa depan JCorp dan pekerja itu sendiri. Majlis PEDOMAN Johor Corporation 2014 melibatkan anggota pekerja diadakan pada 8 Januari 2014 manakala PEDOMAN Eksekutif diadakan pada 3 Julai 2014.

Selain PEDOMAN, peluang semua anggota pekerja mengemuka dan membincangkan isu melibatkan tugas, operasi serta penambahbaikan secara langsung dengan Presiden \& Ketua Eksekutif JCorp adalah terbuka melalui Sesi Bersama Presiden. Sesi ini turut menzahirkan keterbukaan pihak kepimpinan dalam melaksanakan urus tadbir organis.asi. ${ }^{64}$

JCorp juga mengambil langkah bijak dengan mengharamkan penggunaan perkataan kakitangan, dan sebaliknya menggunakan panggilan warga kerja. Semua ahli JCorp sama ada mereka yang terdiri daripada pengurusan tertinggi, para eksekutif, pekerja sokongan sehinggalah kepada pekerja am dipangggil sebagai warga kerja JCorp. Pendirian kepimpinan JCorp dalam konteks ini dapat dlihat dengan kenyataan yang dibuat oleh Mohd Ali seperti berikut ${ }^{65}$ :

"JCorp dengan tegas dan secara rasmi mengharamkan penngunaan istilah "kakitangan", kerana jelas sekali ia bertentangan dengan matlamat menjadikan warga kerjanya berdaya fikir tinggi dalam konteks suasana ekonomi yang

\footnotetext{
${ }^{63}$ Mohd Ali, Khalifah Ganti Superman, t.h.

${ }^{64}$ JCorp, Laporan Tahunan JCorp (Johor BahruJabatan Penerbitan JCorp. 2014, 2015).

${ }^{65}$ Mohd Ali, Khalifah Ganti Superman, 244-245.
} 
dipacu pengetahuan. Anggota yang "tidak berkepala" tidak dapat menyumbang apa-apa dalam suasana ini. "Kakitangan" juga tidak menepati ajaran Islam yang menggalakkan kita menghormati semua sebagai insan kamil. Lebih-lebih lagi dalam sebuah organisasi korporat seperti JCorp yang bercitacita menjayakan Jihad Bisnes. Kejayaan perjuangan bertaraf jihad cuma boleh dicapai setelah semua anggota terbabit dalam menjayakan matlamat besar ini sedar akan peranan penting mereka, menghormati diri sendiri dan bangga dengan tanggungjawab masing-masing, besar jiwa, hebat keyakinan diri, serta bersikap gagah dan berani".

JCorp sebagai entiti awam juga tidak sekali-kali mengabaikan pendedahan dan komunikasi kalangan anggota pekerjanya dengan komuniti setempat mahupun masyarakat terbanyak. Ini dilakukan dengan melibatkan mereka dalam program kebajikan, kemasyarakatan, pendidikan, sukan dan rekreasi mahupun program ilmiah dan keagamaan yang dilaksanakan secara terancang sepanjang ${ }^{66}$.

Bagi tujuan mengenalpasti dan memantau tahap kepuasan anggota pekerja dan aspek yang menyumbang kepada ketidakpuasan hati anggota pekerja, JCorp melaksanakan satu kajian menyeluruh melalui soal selidik secara atas talian. Seramai 308 anggota pekerja (91 peratus) terlibat dengan soal selidik itu. Hasil soal selidik menunjukkan tahap kepuasan bagi kebanyakan warga kerja JCorp adalah tinggi ${ }^{67}$.

Hasil kajian menunjukkan pemimpin JCorp membuka ruang komunikasi yang luas agar komunikasi berkesan dapat dihidupkan. Kepimpinan JCorp telah meletakkan setiap individu warga kerjanya sebagai aset penting dan wajar diberi layanan komunikasi yang bagus. Kepimpinan JCorp juga menunjukkan kebijaksanaan dan keberanian dalam menghapuskan pengunaan panggilan "kakitangan", yang mana ini usaha tersebut berjaya mencipta rasa kebersamaan dalam kalangan seluruh warga kerja. Langkah ini telah memudahkan komunikasi dan menjadikan segala gerak kerja menjadi mudah, termasuklah dalam usaha untuk mengamalkan etika kerja Islam di JCorp. Komunikasi berkesan menyuburkan lagi etika kerja Islam di JCorp seperti semangat kerjasama dan

\footnotetext{
${ }^{66}$ JCorp, Laporan Tahunan JCorp, 2013, 2014).

${ }^{67}$ JCorp, Laporan Tahunan JCorp, 2014, 2015).
} 
musyawarah. Hasil kajian ini mempunyai kaitan dengan Siti Arni, Bharudin dan Raja Hisyamudin (2010) ${ }^{68}$ yang menekankan komunikasi berkesan antara pihak pengurusan dan pekerja. Hasil kajian juga menunjukkan warga kerja menjalin komunikasi yang baik dengan masyarakat luar. Kepimpinan JCorp turut menunjukkan sensitiviti dengan menjalankan soal selidik tentang tahap kepuasan warga kerja JCorp.

\section{Pembuatan Keputusan}

Mohd Ali menjelaskan bahawa pengurusan JCorp bukan menggunakan konsep pengurusan barat secara melulu, tetapi telah disesuaikan dengan pengurusan berasaskan kaedah Islam. Model Islamik yang diamalkan di JCorp difokuskan bagi membina kekuatan korporat dengan menerapkan nilai Islam sepenuhnya ke dalam amalan perniagaannya. Struktur organisasi, sususan strategi, sistem pengurusan dan budaya korporatnya dirangka untuk menepati prinsip Islam. Teras motivasi di JCorp ialah tenaga rohaniah Islam cetusan Jihad Bisnes. Mohd Ali penuh yakin bahawa ciri-ciri Islam telah memberi kekuatan dan semangat juang luar biasa kepada barisan kepimpinan serta semua lapisan anggota JCorp (Mohd. Ali, 2013). Bagi Mohd. Ali, tenaga rohani berasaskan semangat jihad bisnes memberi kekuatan kepada organisasi korporat seperti JCorp, yang hari ini dilihat menerajui beberapa bisnes dan industri strategik negara dan mengimbangi kuasa korporat swasta menegakkan keadilan ekonomi Malaysia. Beliau berkeyakinan tinggi bahawa pilihan berjihad dalam aman, khasnya jihad pembangunan termasuk Jihad Bisnes, lebih menepati matlamat Maqasid As-Syariah, yang menjanjikan masa depan lebih bermakna di segi penyediaan peluang pekerjaan dan pembangunan sosial serta ekonomi. Mohd Ali juga memberi peringatan bahawa keghairahan usahawan Melayu yang menciplak pendekatan barat seperti sikap individualistik dan rakus dalam menguruskan organisasi korporat boleh mengancam masa depan ekonomi orang Melayu dan umat Islam di Malaysia ${ }^{69}$.

${ }^{68}$ Siti Arni, Bharudin dan Raja Hisyamudin, Suntikan Nilai-Nilai Islam,108, t.h.

${ }^{69}$ Sinar Harian, "Jangan Takut Berjihad, dicapai 15 Januari 2015, http://www.sinarharian.com.my/kolumnis/muhammad-ali-hashim/jangantakut-berjihad-1.334125. 
Model Islamik dalam pengurusan yang diamalkan di JCorp memberi kekuatan kepada JCorp untuk membuat keputusankeputusan besar yang bukan hanya selari dengan kehendak Islam, tetapi juga amat penting untuk menjaga kepentingan semua pihak. Pemimpin JCorp telah mengambil beberapa keputusan penting untuk memperkukuhkan urus tadbir korporatnya. Misalnya, pada 2013, JCorp telah secara rasmi membuat Ikrar Integriti Korporat. JCorp juga melantik seorang pegawai Suruhanjaya Pencegahan Rasuah Malaysia (SPRM) untuk berkhidmat di ibu pejabat bagi mengesan lebih awal sebarang elemen yang menjurus ke arah penyelewengan kuasa atau rasuah dalam apa jua bentuk dan skala $^{70}$.

Rentetan daripada itu, JCorp dan syarikat dalam Kumpulan telah melaksanakan beberapa inisiatif bagi memastikan program integriti tidak berakhir begitu sahaja. Antara polisi yang dilaksanakan di JCorp dan syarikat dalam Kumpulan adalah Polisi Tiada Hadiah dan Keraian yang diperkenalkan pada 21 Julai 2014. Di antara tujuan polisi ini adalah seperti berikut ${ }^{71}$ :

i. Untuk mewujudkan budaya tidak menerima apa-apa hadiah atau keraian sebelum, semasa atau selepas menunaikan tanggungjawab daripada mereka yang ada urusan rasmi dengan anggota pekerja.

ii. Untuk mengelakkan anggota pekerja berada dalam keadaan serba salah semasa membuat sesuatu keputusan atau mengelak daripada berlakunya konflik kepentingan.

iii. Untuk mengelakkan tohmahan dari mana-mana pihak bahawa hadiah atau keraian yang diterima adalah rasuah yang boleh menjejaskan nama baik dan reputasi JCorp dan syarikat dalam Kumpulan.

Hasil kajian menunjukkan kepimpinan JCorp telah memutuskan untuk menggunakan model Islamik sebagai sumber kepada gaya pengurusannya. Sehubungan dengan itu, langkahlangkah yang diambil untuk memperkukuhkan urus tadbir korporat juga menunjukkan kesungguhan pemimpin JCorp untuk melahirkan pengurusan dan warga kerja yang jauh daripada rasuah, salah laku dan pecah amanah. Langkah-langkah yang telah diambil ini menjadikan warga kerja JCorp lebih berhati-hati, dan

\footnotetext{
${ }^{70}$ JCorp, Laporan Tahunan JCorp, 2013, 2014).

${ }^{71}$ JCorp, Laporan Tahunan JCorp, 2014, 2015).
} 
memberi motivasi kepada mereka untuk mengamalkan sikap yang betul dalam bekerja agar segala perbuatan salah laku dapat dielakkan. Ini secara langsung telah memberi dorongan yang tinggi kepada pengamalan etika kerja yang baik yang selari dengan kehendak Islam di organisasi JCorp seperti amanah dan disiplin. Hasil kajian ini selari dengan Suraiya (2011) ${ }^{72}$ yang menegaskan bahawa seorang pemimpin perlu berfungsi sebagai model kepada amalan-amalan beretika dalam organisasi, memberi ganjaran dan hukuman bagi menguatkuasakan perlakuan dikehendakki, membendung perlakuan tidak dikehendakki dan mewar-warkan etika kepada seluruh ahli organisasi melalui program tertentu. Kebijaksanaan membuat keputusan dalam kalangan pimpinan JCorp untuk mengamalkan Model Pengurusan Islamik dan memantapkan urus tadbir korporatnya telah membina asas yang kukuh dalam usaha melahirkan warga kerja yang amanah dan berhati-hati.

\section{Pemantauan}

Mohd Ali menegaskan bahawa tindakan membangunkan iman sahaja tidak mencukupi, sekiranya tidak diiringi sistem kawalan yang mantap. Borang Perakuan Peradaban yang dikenali sebagai mekanisme nahi mungkar diperkenalkan pada 1996, digunakan untuk mencegah rasuah. Ia bukan hanya mencegah rasuah skala kecil, malahan mencegah rasuah yang dilakukan pada skala besar yang melibatkan ramai pekerja ${ }^{73}$. Keyakinan Mohd Ali ini dapat dilihat melalui kenyataan beliau sebagaimana berikut:

"JCorp yakin penekanan ke atas pembudayaan nilai amanah yang disusuli dengan kaedah Borang Perakuan Peradaban "nahi mungkar" ini dapat memantapkan lagi usaha untuk menerap nilai kejujuran dan menginstitusikan amanah ke dalam gerak nadi korporatnya. Saya pasti sistem "nahi mungkar" JCorp ini tidak dapat menjamin terhapusnya sama sekali salah laku dan pecah amanah dalam JCorp. Apa pun, saya yakin ia sangat berkesan untuk mengelakkan berlakunya penyelewengan besar-besaran dan korupsi yang dirancang melibatkan ramai anggota secara berterusan".

\footnotetext{
${ }^{72}$ Suraiya, Model Kepemimpinan Etika, 29, t.h.

${ }^{73}$ Mohd Ali, Khalifah Ganti Superman, 365.
} 
Laporan Tahunan JCorp $2014(2015)^{74}$ menunjukkan bahawa JCorp menggunakan Borang Perakuan Peradaban untuk mewujudkan saluran komunikasi bagi penyampaian maklumat yang digunakan oleh anggota pekerja untuk menyalurkan informasi terus kepada Presiden \& Ketua Eksekutif jika mereka mempunyai sebarang maklumat mengenai salahlaku atau penyelewengan dalam kalangan anggota pekerja.

Manakala bagi menggalakkan ketelusan kepada semua rakan niaga, JCorp turut memanjangkan Borang Perakuan Peradaban ini kepada kontraktor dan pembekal. Di samping itu, JCorp turut melaksanakan Polisi 'Whistleblowing'. Polisi 'Whistleblowing' ini bertujuan memudahkan anggota pekerja JCorp, kontraktor, pembekal, ejen atau mana-mana pihak luar untuk membuat pendedahan berkaitan apa-apa kelakuan tidak wajar dalam pengetahuan mereka. Polisi ini juga bertujuan memberi perlindungan ke atas identiti pemberi maklumat yang membuat pendedahan kelakuan tidak wajar seperti di bawah Seksyen 6 Akta Perlindungan Pemberi Maklumat 2010. Sebarang aduan yang diterima akan dibawa kepada Jawatankuasa Menilai Maklumat untuk tindakan selanjutnya.

Di samping itu, sebuah jawatankuasa baru telah ditubuhkan iaitu Jawatankuasa Menilai Maklumat. Tujuan jawatankuasa ini adalah untuk mengkaji dan menilai informasi atau aduan yang diterima, sama ada melibatkan jenayah, pelanggaran kod etika dan pelaksanaan bisnes atau sebaliknya ${ }^{75}$.

Pemimpin yang sering melakukan pemantauan dapat memberikan sesuatu arahan, nasihat dan keputusan yang berkesan kepada pekerja dalam pelaksanaan etika kerja Islam. ${ }^{76}$ Hasil kajian menunjukkan bahawa pemimpin JCorp mengambil langkah bijak dengan mengadakan mekanisme pemantauan seperti Borang Perakuan Peradaban, Polisi 'Whistleblowing' dan Jawatankuasa Menilai Maklumat. Mekanisme-mekanisme tersebut merupakan alat kawalan dan pencegahan agar warga kerja JCorp dapat menghindarkan diri daripada salah laku kerana perbuatan seperti itu sudah tentunya dapat dikesan dengan adanya sistem pemantauan yang ketat. Kepimpinan JCorp mengambil langkah ke

\footnotetext{
74 JCorp, Laporan Tahunan JCorp, 2014, 2015).

75 JCorp, Laporan Tahunan JCorp, 2014, 2015).

${ }^{76}$ Sharifah Hayaati dan Mohd Mauli, Etika Penyelesaian Konflik, 16.
} 
hadapan dengan melaksanakan Polisi 'Whistleblowing' untuk memberi perlindungan kepada pemberi maklumat mengenai perbuatan salah laku. Polisi ini yang sudah lama diperkenalkan di negara-negara maju amat penting dilaksanakan untuk memantapkan lagi sistem pemantauan. Sistem pemantauan ini sudah pasti akan mencegah perbuatan salah laku dan dalam masa yang sama menyuburkan budaya dan etika kerja yang selari dengan kehendak Islam seperti menjauhi rasuah, penipuan, bersifat amanah dan telus. Dalam dunia korporat yang mana banyak terlibat dengan pengurusan kewangan dan agihan kontrak misalnya, sistem kawalan yang mantap amat penting untuk mencegah perbuatan salah laku dan ketirisan hasil.

\section{Sistem Ganjaran}

Pemimpin di JCorp mengambil berat akan aspek ganjaran yang disediakan kepada warga kerja. Pada 2013, JCorp telah melaksanakan skim gaji baru JCorp yang setaraf dengan badanbadan korporat lain di Malaysia. Manakala Petunjuk Prestasi Utama (PPU) digunakan untuk menilai prestasi warga kerja. Setiap anggota pekerja dinilai berdasarkan pencapaian PPU individu yang telah dipersetujui pada awal tahun. Jabatan Pembangunan Modal Insan bersama setiap Ketua Jabatan yang terbabit akan membentangkan keputusan penilaian tersebut kepada Jawatankuasa Penilaian Prestasi. Pekerja yang cemerlang diberi ganjaran, manakala pekerja berprestasi rendah diberi peringatan. JCorp juga menerima pakai Sistem Penilaian Timbal Balik di mana Eksekutif Kanan ke atas akan dinilai oleh anggota pekerja bawahan dan juga rakan sekerja. Warga kerja cemerlang bukan sahaja berpeluang menerima Anugerah Kecemerlangan, tetapi juga diberi kepercayaan untuk memegang jawatan tinggi dan menerajui anak-anak syarikat JCorp, misalnya melalui Skim Usahawan Intrapreneur ${ }^{77}$.

JCorp juga melaksanakan pengurusan pengetahuan yang mana ianya merupakan satu kaedah memberi peluang kepada warga kerja JCorp memberikan pelbagai maklumat menerusi percambahan cadangan dan idea. Dalam konteks ini, melalui Skim Cempaka dan Konvensyen Kualiti yang dilaksanakan, mereka yang menyumbangkan idea-idea bernas dan inovatif yang boleh

77 JCorp, Laporan Tahunan JCorp, 2014, 2015). 
dilaksanakan akan mendapat pengiktirafan atau ganjaran daripada pihak pengurusan $^{78}$.

Menurut Autry $(1991)^{79}$, kepimpinan bukan sahaja mengawal orang lain, tetapi juga mengambil berat akan orang lain dan menjadi satu sumber rujukan yang bermakna kepada mereka. Hasil kajian menunjukkan bahawa kepimpinan JCorp menyediakan skim dan mekanisme ganjaran yang bagus untuk warga kerjanya. Ganjaran yang diberikan bukan hanya meliputi aspek prestasi kerja, malahan turut mengambilkira aspek kebolehan memberi idea yang bernas. Ganjaran seperti ini memberi momentum kepada warga kerja agar bekerja bersungguhsungguh dan bersikap kreatif serta inovatif untuk mencapai kecemerlangan dalam pekerjaan. Kepimpinan JCorp juga mengambil langkah unik dengan melaksanakan Sistem Penilaian Timbal Balik. Sistem ini sudah pasti memberi dorongan kepada Pegawai Kanan dan ke atas untuk bekerja dengan cemerlang dan memberi contoh tauladan kepada orang lain kerana mereka turut dinilai oleh warga kerja JCorp yang lain. Suasana ini akhirnya menyuburkan lagi perlaksanaan etika kerja Islam yang menekankan amalan baik seperti mementingkan integiriti, berdisiplin, rajin bekerja, berani member idea dan kreatif dalam kalangan warga kerja JCorp.

\section{Persekitaran}

Pemimpin JCorp berusaha gigih untuk mewujudkan suasana kerja yang kondusif kerana ianya penting untuk merangsang kecemerlangan. Misalnya, dengan menggalakkan aktiviti peningkatan budaya kualiti dan inovasi melalui program Innovative \& Creative Circle (ICC), Cross Functional Team (XFT) serta Cadangan dan Idea Ke Arah Kecemerlangan (CEMPAKA) sejak 1995. Kemuncak program ini adalah penganjuran Hari Mekar yang menggabungkan penyertaan syarikat dalam Kumpulan JCorp sebagai platform perkongsian idea dan aktiviti kualiti di antara syarikat dalam Kumpulan. Hari Mekar 2013 dianjurkan pada 15 \& 16 Januari 2014 oleh Kulim (Malaysia) Berhad dengan tema 'Transformation Through

\footnotetext{
78 JCorp, Laporan Tahunan JCorp, 2014, 2015).

79 James A, Autry, Love and Profit: The Art of Caring Leadership (New York: Avon Books, 1991).
} 
Quality'. Pada Hari Mekar Ke-18 itu juga buat pertama kalinya JCorp memperkenalkan Kategori Persekitaran Berkualiti (QE/5S) bertujuan menggalakkan penyertaan dan mengiktiraf pelaksanaan amalan QE/5S di jabatan dan syarikat dalam Kumpulan. Secara keseluruhannya sepanjang 2014, terdapat peningkatan yang memberangsangkan dari segi pencapaian dalam aspek kualiti yang boleh dilihat melalui penerimaan pelbagai pengiktirafan dan pensijilan dalam Kumpulan JCorp (Laporan Tahunan JCorp 2014, 2015).

Pemimpin juga mestilah mencipta dan mempertahankan persekitaran organisasi bagi membolehkan semua warga kerja melibatkan diri secara aktif dalam usaha untuk mencapai matlamat organisasi. ${ }^{80}$ Hasil kajian menunjukkan bahawa kepimpinan JCorp amat mementingkan perlaksanaan program kualiti. Program kualiti sebenarnya bukan sahaja penting untuk memenuhi kehendak masyarakat dan pelanggan, malahan ianya lebih penting lagi berfungsi untuk meningkatkan keberkesanan pengurusan organisasi JCorp. Program-program pengurusan kualiti yang dilaksanakan di JCorp sebenarnya menyediakan platform yang bagus untuk pelaksanaan etika kerja Islam. Ini kerana program kualiti memberi penekanan kepada kerja keras, pematuhan kepada prosedur kerja, inovasi, penambahbaikan berterusan, kecemerlangan dan pelbagai lagi. Ciri-ciri ini adalah seiring dengan etika kerja Islam seperti amanah, dispilin, syura, bersungguh-sungguh, penambahbaikan berterusan (istiqamah) dan pembaharuan (islah). Justeru itu, persekitaran kerja yang mementingkan kualiti sebenarnya merupakan platform yang bagus untuk menyemarakkan lagi pelaksanaan etika kerja Islam di JCorp.

\section{Penutup}

Hasil kajian menunjukkan bahawa pemimpin organisasi korporat JCorp telah memainkan 6 peranan dalam pelaksanaan etika kerja Islam. 6 peranan tersebut ialah berkenaan dengan latihan, komunikasi, pembuatan keputusan, pemantauan, sistem ganjaran dan persekitaran. Kesemua 6 peranan tersebut telah berfungsi sebagai pemangkin yang menyuburkan pelaksanaan etika kerja Islam di JCorp. Pemimpin JCorp menunjukkan kebijaksanaan dan

${ }^{80}$ Siti Arni, Bharudin dan Raja Hisyamudin, Suntikan Nilai-nilai Islam, 106. 
komitmen yang tinggi dengan mengambil langkah-langkah pragmatik untuk memastikan etika kerja Islam dapat dilaksanakan dengan efektif di JCorp.

Dapat disimpulkan bahawa pemimpin di JCorp menepati istilah 'Malik' yang dijelaskan dalam Al-Quran iaitu individu yang mempunyai kualiti dan ciri sebagai pemimpin yang baik. Pemimpin di JCorp memilikki kebijaksanaan dengan memainkan peranan yang betul dan berkesan untuk menjayakan perlaksanaan perlaksanaan etika kerja Islam di kalangan seluruh warga kerja. Pemimpin di JCorp telah berjaya mewujudkan persekitaran yang positif untuk merangsang motivasi warga kerja agar mereka terdorong untuk mengamalkan etika Islam dalam pekerjaan mereka. Selain itu, pemimpin JCorp juga memilikki kemahiran dalam memilih dan menentukan peranan penting yang perlu dimainkan oleh mereka dalam usaha memupuk cara kerja yang selari dengan etika kerja Islam di kalangan warga kerja.

Jelaslah bahawa pemimpin dalam sesebuah organisasi sememangnya memainkan peranan penting serta memberi impak yang tinggi kepada pelaksanaan etika kerja Islam. Dengan adanya komitmen di pihak pemimpin, maka ahli-ahli organisasi akan lebih terdorong untuk melaksanakan etika kerja Islam dengan penuh kesedaran dan penghayatan. Hal ini secara langsung telah melancarkan lagi pelaksanaan etika kerja Islam dalam kalangan seluruh anggota organisasi.

Hasil kajian ini menyumbang secara signifikan kepada pembangunan ilmu kerana kajian empirikal mengenai peranan pemimpin dalam pelaksanaan etika kerja Islam setakat ini masih amat kurang dijalankan. Selain itu, kajian ini mengetengahkan hasil kajian mengenai peranan pemimpin dalam perlaksanaan etika kerja Islam dalam konteks persekitaran yang khusus iaitu di Malaysia.

Hasil kajian ini juga memberi gambaran kepada para pemimpin organisasi mahupun pemimpin korporat untuk memahami dan mempelajari tentang peranan yang perlu dimainkan oleh mereka dalam usaha untuk melaksanakan etika kerja Islam secara efektif. Para pemimpin organisasi juga boleh mengambil iktibar daripada kegigihan dan keyakinan yang ditunjukkan oleh pemimpin JCorp dalam usaha mereka mengguna pakai asas Islam untuk mengurus sebuah organisasi yang besar 
seperti JCorp. Pemimpin JCorp mempunyai keyakinan yang tinggi terhadap sistem pengurusan Islam, dan keyakinan tersebut disusuli dengan tindakan-tindakan pragmatik bagi memastikan etika kerja Islam dapat dilaksanakan secara mapan di JCorp.

Kajian ini menumpukan kepada organisasi JCorp sahaja. Justeru itu, kajian akan datang boleh dilakukan ke atas organisasi korporat lain seperti Tabung Haji, Kumpulan Wang Simpanan Pekerja dan Pusat-Pusat Zakat di Malaysia. Kajian juga boleh dilanjutkan kepada sektor awam, sama ada agensi di peringkat kerajaan pusat mahupun kerajaan negeri. Kajian ini memberi tumpuan kepada peranan pemimpin, maka pengkaji akan datang boleh melanjutkan kajian ini. Misalnya dengan melihat kepada aspek cabaran yang dihadapi oleh pemimpin organisasi dalam usaha melaksanakan etika kerja Islam secara berkesan.

\section{Bibliografi}

A.A, Muhammad. Nayl al-Awțar Syarh Muntaqā al-Akhbar. Beirut: Dār Al-Ma'rifah, 1998.

A.H.M Muslim, "Sahih Muslim," Kitab al-Imārah, Bab al-Imām Junnah yuqatalu min waraihi wa yuttaqa bih, Hadis no. 1841 (Riyadh: Bayt al-Afkar al-Dawliyah, 1998), 769.

Al-Baghāwī, Abū Muḥammad al-Husayn Ibn Mas'ūd Ibn Muḥammad al-Farra' Ma 'áim al-Tanzīl. Lubnan: Dār alMa'rifah, 2012.

Al-Bukhārī, Abū Abd allāh Muhammad Ismā'īl. "Sahih alBukhari," Kitab al-'Itqu, Bāab al-'Abd Ra'in fī ma lā Saidihi, no.Hadith 2558. Kaherah: Maktabah al-Salafiyyah, 1982.

Al-Maraghī, Aḥmad Mușțafā. Tafsīr al-Maraghī. Beirut: Dār alFikr, 1974.

Al-Mawardi, Abū Hasan. Al-Nukat wa al-'Uyūn. Beirut: Dār alKutub al-'Ilmiyyah, t.t.

Al-Qurțubī, Abū 'Abd Allāh Muḥammad bin Aḥmad al-Anșārī. Al-Jāmi' li Ahkām al-Qur'an. Tahq. 'Imād Zakī al-Barudī dan Khawrī Sa'īd. Kaherah: al-Maktabah al-Tawfiqiyyah, t.t.

Al-Raz̄̄ Fakhr al-Dīn 'Umar bin al-Husayn al-Taymī al-Bakrī. Tafsīr al-Kabìr. Beirut: Dār al-Kutub al-'Ilmiyyah, 2000.

Al-Ṭabarī, Abū Ja'far Muhammad bin Jarīr. Jāmi' al-Bayān 'an

Ta'wīl al-Qur'ān. Cet. 3. Mesir: Sharikah Maktabah wa Țab'ah Muștafāa al-Bābī al-Ḥalabī wa Awlāduh, 1968. 
Al-Zamakhsharī, Abū Qāsīm Al-Kashshāf. Cet. 3. Beirut: Dār alMa'rifah, 2009.

Al-Zuhayli, Wahbah. al-Fiqh al-Islāmī wa Adillatuh. Cet. 4. Dimashq: Dār al-Fikr, 1997.

Aminuddin bin Mohd Yusof. Siri Analisis Psikologi Kepimpinan. Kuala Lumpur: Dewan Bahasa dan Pustaka, 1990.

Autry, James A. Love and Profit: The Art of Caring Leadership. New York: Avon Books, 1991.

Autry, James A. Love and Profit: The Art of Caring Leadership. New York: Avon Books, 1991.

Baharom bin Mohamad, Mohamad Johdi bin Salleh dan Che Noraini binti Hashim, "Kepimpinan Pendidikan Berkesan". Kertas kerja, Seminar ke-4 Kepengetuaan Kebangsaan, Universiti Malaya, 12 Mac 2009.

Braun, V. and Clarke, V. "Using Thematic Analysis in Psychology", Qualitative Research in Psychology 3 (2006).

F.R. Robert, and Stone, A.Gregory. "A Review of Servant Leadership Attributes: Developing a Practical Model". Leadership and Organization Development Journal 23, no 3, (2002).

Ibn Kathir, Abū al-Fị̣ā’ Ismā‘n̄l al-Qurashiy al-Dimashqī. Tafsīr al-Qur'ān al-'Azì̄m. Kaherah: Dār al-Hadīth, 2002.

Ibn Manzūr, Muhammad Ibn Mukarram. Lisān al- 'Arab. Beirut: Dār al-Ihyā' Turath al-'Arabi, 1988.

Ibn Manzūr, Muhammad Ibn Mukarram. Lisān, al-'Arab. Beirut: Dār al-Iḥyā' Turath al-'Arabiy, 1988.

Ibn-Taymiyyah. Al-Siyāsah al-Syar'iyyah fi Islah al-Ra'iy wa alRa'iyyah. Beirut: Dār al-Fikr al-Lubnani, 1992.

K. Daniel dan Khan, Robert L. The social psychology of organization. New York: John Wiley. 1966.

Khasif Muhammad, Run Ernest Cyril De, Abdul Rehman Mohsin and Ting Hiram, "Bringing Islamic Tradition Back to Management Development: A New Islamic Dawah Based Framework to Foster Workplace Ethics", Journal of Islamic Marketing 6, no 3, (2015), 429-446.

Lokman bin Abdul Rasol, Pengurusan Kualiti Menurut Perspektif Islam: Kajian di Majlis Perbandaran Subang Jaya. Disertasi, Universiti Malaya, 2013. 
Lokman bin Mohd Tahir dan Hamidon binti Abdul Rahman. "Peranan Etika dalam Kepimpinan Pendidikan". Jurnal Pendidikan Universiti Teknologi Malaysia 8 (2002).

Mohamed Farah Abdi, Siti Fatimah binti Wira Muhamad Nor dan Nor Zuhairatun binti Md. Radzi. "The Impact of Islamic Work Ethics on Job Performance and Organizational Commitment". Paper, Asia-Pacific Business Research Conference, Kuala Lumpur, 17-18 February 2014.

Mohamed Sulaiman, Nur Arfifah binti Abdul Sabian and Abdul Kadir bin Othman. "The Understanding of Islamic Management Practices Among Muslim Managers in Malaysia". Asian Social Science 10, no 1 (2014).

Mohd Ali bin Hashim. "Khalifah Ganti Superman". Kuala Lumpur: Utusan Publications \& Distributers, 2013.

Muhammad Shakil bin Ahmad. "Work Ethics: an Islamic Prospective". International Journal Of Human Sciences 8, no 1 (2011).

Nor Azzah Kamri dan Siti Arni Basir. "Etika di Institusi Islam:

Penelitian Ke Atas Faktor Pendorong Pelaksanaannya", dalam Islamic Perspective on Management: Contemporary Issues, ed. Nor Azzah Kamri, Azian Madun. and Suhaili Sarif. Kuala Lumpur: Akademi Pengurusan YaPIEM, 2013.

Noraini Misran dan Ahmad Othman. "Hubungan Ciri-Ciri Kepimpinan Berorientasikan Pekerja Terhadap Kejayaan Projek di Kalangan Kontraktor dalam Industri Pembinaan". International Conference on Management, Kuala Lumpur, 3 Mac 2011.

Sarvinder Singh dan Ahmad bin Esa, "Kepimpinan dalam Menghadapi Isu-Isu Semasa Pendidikan". Makalah, Seminar Kebangsaan Pengurusan Pendidikan Universiti Tun Hussein Onn Malaysia, 16 Oktober 2008.

Sharifah Hayaati binti Syed Ismail al-Qudsy dan Mohd Mauli bin Abu Bakar. "Etika Penyelesaian Konflik dalam Pentadbiran Islam: Suatu Perbandingan". Jurnal Syariah 14, no 1 (2006).

Sheikh Abdul Munir bin Sheikh Abdul Rahim. "Etika Kepimpinan Menurut Islam: Suatu Kajian di Kalangan Pemimpin Melayu Peringkat Negeri di Pahang Darul Makmur". Disertasi, Universiti Malaya, 2008. 
Shukri bin Ahmad dan Musa Yusuf Owoyemi, "The Concept of Islamic Work Ethic: An Analysis of Some Salient Points in the Prophetic Tradition". International Journal of Business and Social Science 3, no 20 (2012).

Suraiya binti Ishak. "Model Kepemimpinan Etika Berlandas Sirah Nabi Muhammad SAW", Jurnal Hadhari 3, no 2 (2011).

Thomas Oakland, "The Bell Curve: Some Implication The Discipline of School Psychology and Practices Of School Psychology". School Psychology Review 24, no 1 (1995), 20-26. Yin, R.K., Case Study Research. $3^{\text {rd }}$ ed. (t.tp.: Sage Publications 2014). 
Arni, Syafiyah, Zaidi dan Munirah, Peranan Pemimpin dalam Pelaksanaan Etika 